İş ve İnsan Dergisi I The Journal of Human and Work

Y1l | Year: Nisan | April 2016

Cilt-Say1 | Volume-Issue:3(1)

ss I pp: $1-20$

doi: 10.18394/iid.15648

e-ISSN 2148-967X

http://dergipark.ulakbim.gov.tr/iid/

Araştırma Makalesi

\title{
Ölçek Uyarlamada Metodoloji Sorunu: Yönetim ve Örgüt Alanında Uyarlanan Ölçekler Üzerinden Bir Araştırma
}

\author{
Methodological Issues in Scale Adaptation: A Study on Adapted Scales in the \\ Management and Organization Field
}

\author{
Mehmet Emin Bayık" \\ Kara Harp Okulu
}

\author{
Sait Gürbüz \\ Kara Harp Okulu
}

MAKALE BİLGISI

Anahtar Kelimeler:

Ölçek uyarlama, Çeviri,

Geri-çeviri, Yanlılık

Denklik, İçerik analizi.

Tarihler :

Geliş 19 Ocak 2016

Düzeltme geliş 02 Mart 2016

Kabul 03 Mart 2016
ÖZ

Bu çalışmada; yanlıllk, denklik ve ölçek uyarlama çalıșmalarında uygulanması gerekli olan hususlara açıklık getirilmesi; yönetim ve örgüt alanında, yabancı dilde geliştirilmiş ölçeklerin Türkçe'ye uyarlanması çalışmalarında hâlihazırda nasıl bir uygulama izlendiğinin tespit edilmesi ve bu çalışmalar için bazı öneriler getirilmesi amaçlanmuştır. Bu kapsamda, 2010-2015 yılları arasında yönetim ve örgüt alanında yapılmış olan ölçek uyarlama çalışmaları $(n=45)$ içerik analizi ile incelenerek ölçek uyarlama çalışmalarında genel eğilimler ve uygulamalar tespit edilmiştir. Elde edilen bulgular neticesinde; ölçek uyarlama çalışmalarındaki uygulamaların, araştırmacılar arasında büyük ölçüde farklılıklar gösterdiği ve ölçek uyarlama çalışmalarında ortak bir metodoloji takip edilmediği tespit edilmiştir. Çallşmada, ölçek uyarlama çalıșmalarında metodoloji birliği sağlamak ve hatalı uygulamaları en az düzeye indirgemek amacıyla ölçek uyarlaması yapan araştırmacılar için öneriler sunulmuştur.

\section{ARTICLE INFO}

\section{Keywords:}

Scale adaptation,

Translation, Back-

translation, Bias,

Equivalence, Content analysis.

Article history:

Received 19 January 2016

Received in revised form 02

March 2016

Accepted 03 March 2016

\begin{abstract}
A B S T R ACT
The purpose of the present study is to clarify the concepts of bias and equivalence as well as the procedures to be applied in the scale adaptation studies; to identify the current trends and practices in the adaptation of the scales to Turkish language; and to make some suggestions for scale adaptation procedures. Within this framework, the scale adaptation studies $(n=45)$ conducted during 2010-2015 were content analyzed, and the current trends and practices in scale adaptation were identified. The study findings indicated that there were great differences in the scale adaptation procedures followed by researchers and that there was no commonly accepted methodology for scale adaptation. A series of suggestions were proposed to the researchers to ensure a uniform methodology and minimize inaccurate practices in the scale adaptation studies.
\end{abstract}

*Iletişim Kurulacak Yazar: Mehmet Emin BAYIK, Kara Harp Okulu, Savunma Bilimleri Enstitüsü, Ankara, Türkiye. E-posta: mebayik@kho.edu.tr 


\section{GİRIŞ}

Yönetim ve örgüt alanında kültürlerarası çalışmaların artmasıyla birlikte, bir kültürel bağlamda geliştirilmiş model, kuram ve veri toplama araçlarının başka bir kültürel bağlamdaki geçerliliğinin sorgulanması hız kazanmıştır. Türkiye'de; genelde sosyal bilimlerde, özelde ise yönetim ve örgüt araştırmalarında, Türkiye bağlamına uygun yeni ölçekler geliştirmek yerine, çoğunlukla, yabancı yazından ithal edilen ölçeklerin kullanıldığ 1 ifade edilebilir. Başka bir dilde oluşturulmuş herhangi bir ölçeğin Türkiye örnekleminde kullanılabilmesi için Türkçe'ye uyarlama işleminin sistematik bir şekilde yapılarak ölçeğin Türkiye örnekleminde psikometrik açıdan gerekli özellikleri taşıdığının kanıtlanması gerekmektedir. Uyarlama sürecinde, sadece ölçeğin Türkçe'ye çevirisine odaklanılması yeterli görülmediğinden, Uluslararası Test Komisyonu (International Test Commission-ITC) tarafindan 1993 yılında yayınlanmış olan yönlendirici ilkelerde (International Test Commission, 2005) "çeviri" yerine "uyarlama" nitelendirmesi tercih edilmiştir. Çünkü uyarlama, orijinal dilinden farklı bir dilde kullanılacak olan ölçekler için yapılan işlemleri tanımlayan daha geçerli ve geniş kapsamlı bir terimdir. Çeviri ise bir ölçeğin orijinal dili ile farklı dillerdeki versiyonlarının birbirlerine denk olması amacıyla icra edilen uyarlama sürecinin birçok basamağından sadece birisidir (Hambleton, 1996).

Farklı dillerde olan iki ölçek arasındaki denkliğin ispat edilmesi, özellikle bu iki farklı dili kullanan örneklemler arasında kültürlerarası bir karşılaştırma yapılacağı zaman daha da büyük önem kazanmaktadır (Ægisdóttir, Gerstein \& Çınarbaş, 2008; Van de Vijver \& Hambleton, 1996). Kültürlerarası karşılaştırma yapan çalışmaların istatistiksel olarak anlamlı bulgular raporlamaları halinde; raporlanan farklılıkların, gruplar arasındaki gerçek farklılıklardan mı kaynaklandığı yoksa orijinal dilden farklı bir dile çevirisi yapılmış olan ölçeğin denklik ile ilgili koşulları sağlayamamış olmasından dolayı mı kaynaklandığı yönünde sorunlar ortaya çıkmaktadır (Mallinckrodt \& Wang, 2004). Eğer bir araştırmacı; A kültüründe ve dilinde geliştirilmiş bir ölçme aracı vasıtası ile A ile B kültürlerini karşılaştırarak, $\mathrm{A}$ kültürünün $\mathrm{B}$ kültüründen daha fazla ya da daha az miktarda bir özelliğe sahip olduğuna yönelik bir çıkarımda bulunmak istiyorsa, B kültürü ve dili için kullandığ ölçeğin yanlılığının mevcut olmadığını ve orijinal olan ölçek ile denkliğe sahip olduğunu görgül olarak kanıtlaması gerekmektedir (Ægisdóttir vd., 2008).

Orijinal ölçeğin ilk olarak geliştirildiği kültür ile ölçeğin uyarlama çalışması yapılacak olan hedef kültür arasında "kültürel uzaklık" ne kadar fazla ise yanlılığın mevcut olma ihtimalinin o derecede yüksek olacağı belirtilmektedir (Hambleton, 1996). Kültürel uzaklık; dil, sosyal yapı, din, sosyoekonomik durum, politik sistem, okuma-yazma oranı, vb. farklılıkları yansitmaktadır (Triandis, 2000). Birleşmiş Milletler (BM) tarafindan yıllık olarak yayınlanan İnsan Gelişim Raporu'nda (Human Development Report) yer alan İnsan Gelişim Endeksi'nden (Human Development Index-HDI) elde edilen ülke siralamalarına göre ülkeler arası kültürel uzaklık belirlenebilmektedir (Ægisdóttir vd., 2008). Bu çalışmanın ilerleyen kısımlarında görüleceği üzere, 2010 ile 2015 yılları arasında yönetim ve örgüt alanındaki ölçek uyarlama çalışmalarında $(n=45)$ Türkçe'ye uyarlanan ölçeklerin tamamının Amerika Birleşik Devletleri (ABD) kökenli olduğu tespit edilmiştir. Ölçek uyarlama çalışmalarında ABD kökenli ölçeklerin bu derecede yaygın olarak kullanılmakta olması; özellikle ABD ile Türkiye arasındaki kültürel uzaklığın ölçek uyarlama çalışmaları açısından önemli olduğuna işaret etmektedir. 2015 yılı HDI verileri incelendiğinde, Türkiye'nin sıralaması "72" iken, ABD'nin siralaması "8" olarak belirtilmiştir (United Nations, 2015). Bu değerler, ABD ile Türkiye arasında kültürel uzaklığın yüksek olduğunu ve ABD'den Türkiye'ye ölçek uyarlamasında yüksek düzeyde yanlılık oluşabileceğini göstermektedir. $\mathrm{Bu}$ nedenle $\mathrm{ABD}$ kökenli ölçeklerin Türkçe'ye uyarlama çalışmalarında, yanlılık ve denklik konularında daha dikkatli davranılması gerektiği değerlendirilmektedir.

Metodoloji ve ölçme konuları; sosyal bilim araştırmalarının diğer hiçbir alt dalında, kültürlerarası ve uluslararası karşılaştırmada olduğu kadar zorluğa ve tenkide açık değildir (Johnson, 1998). Ölçek uyarlaması ile ilgili yazın incelendiğinde, ölçeklerin uyarlama çalışmalarının nasıl yapılacağına dair ITC tarafından geliştirilmiş yol gösterici ilkeler (Hambleton, 1996; International Test Commission, 2005; Van de Vijver \& Hambleton, 1996), yanlılığı azaltmaya dair stratejiler (He \& Van de Vijver, 2012; Van de Vijver \& Tanzer, 2004), ölçek uyarlama çalışmaları kapsamında gerçekleştirilen çeviri sürecinde izlenecek basamaklar (Brislin, 1986; Brislin, Lonner \& Thorndike, 1973) gibi bir çeşitlilik ve zenginlik olmasına rağmen yazında henüz standart bir metodolojinin ortaya konulamamış olduğu söylenebilir.

Türkiye'de yapılan araştırmalarda (Çüm \& Koç, 2013; Erdemir, 2008; Güvendir \& Özkan, 2015; Özen, 2000; Öztürk, Eroğlu \& Kelecioğlu, 2015) yabancı dilde geliştirilen ölçeklerin Türkçe'ye uyarlanmasına yönelik çeşitli noksanlıklar/hatalar 
tespit edildiği raporlanmıştır. Örneğin Özen (2000), yönetim/organizasyon yazınında kongre bildirileri (1996-1998 yılları arası) üzerinden yöntem sorununa yöneldiği araştırmasında; araştırmaların \%76,9'unda kullanılan ölçeklerin geçerlilik ve güvenilirlik düzeylerinin hesaplanmadığını veya belirtilmediğini tespit etmiştir. Yine yönetim ve örgüt alanındaki kongre bildirilerini (2002-2007 y1lları arası) inceleyen Erdemir (2008); bildirilerin \%49'unda ölçeklerin uyarlanmadan doğrudan doğruya çevirisinin yapılarak kullanıldığı, \%26'sında hem uyarlama çalıșması yapılmadığ hem de kullanılan ölçeğin kaynağının belirtilmediği, \%87'sinde geçerlilik ile ilgili bulguların belirtilmediği ve \%42'sinde ise güvenilirlik ile ilgili bulguların belirtilmediği sonucuna ulaşmıştır. Eğitim alanında yapılan ölçek uyarlama çalışmalarını (2005-2014 yılları arası) inceleyen Öztürk ve arkadaşları (2015) ise; araştırmaların \%62'sinde ölçüte dayalı geçerliliğin hesaplanmadığını ve \%28,7'sinde ölçek maddelerinin analizlerinin yapılmadığını tespit etmişlerdir. Yine eğitim alanında yapılan ölçek uyarlama çalışmalarını (2006-2014 yılları arası) inceleyen araştırmalarında, Güvendir ve Özkan (2015); çalışmaların sadece \%18,1'inin dil eşdeğerliği için her iki kültüre hâkim tercümanlar seçtiğini ve yine sadece \%24,2'sinin ön deneme uygulaması (ön test) yaptığını tespit etmişlerdir. Çüm ve Koç (2013); psikoloji ve eğitim bilimleri dergilerindeki ölçek uyarlama çalışmaları (20052013 yılları arası) ile ilgili olarak; inceledikleri çalışmaların hiçbirinin ölçeğin hem dilsel hem de kültürel yönden yapısal eşdeğerliğine yönelik rapor sunmadığı, çalışmaların \%85,7'sinin ön test yapılıp yapılmadığına yönelik bilgi vermediği ve \%57,1'inin uygun geçerlilik çalışmaları yapıldığına dair bilgiler rapor etmediği bulgusuna ulaşmışlardır. $\mathrm{Bu}$ bulgular; bahse konu alanlarda, ölçeklerin Türkçe'ye uyarlama süreçlerinde bazı sorunlar olduğunu göstermektedir.

Ölçek uyarlamasına yönelik gereklilikler ve daha önce farklı alanlarda (eğitim, psikoloji, kongreler, vb.) yapılmış çalışmalardan elde edilen bulgular göz önüne alındığında; yönetim ve örgüt alanında yapılan ölçek uyarlama çalışmalarında da hâlihazırda benimsenen ölçek uyarlama yöntem ve süreçlerinin, yazında kabul gören temel ölçek uyarlama ilkelerine uygun olup olmadığının tespit edilmesinin önemli olduğu düşünülmektedir. Buradan elde edilecek bulgular ve ilgili yazındaki temel ilkelerden hareket edilerek ölçek uyarlaması için bir yol haritası önerilmesine ihtiyaç bulunduğu değerlendirilmektedir.

$\mathrm{Bu}$ çalışmada; öncelikle (a) yanlılık, denklik ve ölçek uyarlama çalışmalarında uygulanması gerekli olan hususlara açıklık getirilmesi, daha sonra ise (b) yönetim ve örgüt alanında, yabancı dilde geliştirilmiş ölçeklerin Türkçe'ye uyarlanması çalışmalarında hâlihazırda nasıl bir uygulama izlendiğinin tespit edilmesi ve son olarak (c) yabanc1 dilden Türkçe'ye ölçek uyarlama çalışmaları için bazı öneriler getirilmesi amaçlanmıştır. Bu çalışmanın sonucunda; yabancı dilde hazırlanmış olan ölçeklerin Türkiye örnekleminde kullanımında uygulanan yöntemlere ilişkin nicel veriler ortaya konulması ve ITC ilkeleri ile yazındaki ölçek uyarlama çalışmalarına yönelik hususların sentez edilmesi suretiyle ölçek uyarlama için bazı öneriler sunularak ilgili yazına katkı sağlanması beklenmektedir. Ayrıca yapılacak olan önerilerin, ölçek uyarlama çalışması yapan araştırmacılara yol gösterici nitelikte olacağ düşünülmektedir.

Çalışmada öncelikle ölçek uyarlama çalışmalarına yönelik olarak ITC yönlendirici ilkelerinden bahsedilecek ve daha sonra yanlılık ve denklik konuları ile ilgili hususlar ortaya konulacaktır. Bir sonraki aşamada, bir ölçeğin başka bir dile uyarlanmasında takip edilmesi gereken adımlar ve bu adimlarda uygulanan nitel ve nicel yöntemler tartışılacaktır. Bir sonraki aşamada; 2010 yılından 2015 yılı sonuna kadar yönetim ve organizasyon alanındaki Türkçe'ye ölçek uyarlama çalıșmalarının içerik analizi yapılarak, ölçek uyarlama çalışmalarında takip edilen yöntemlere ilişkin hâlihazırdaki durumun tespitine yönelik bulgular ortaya konulacaktır. Son aşamada ise; ölçek uyarlama çalışmalarındaki uygulamalara yönelik olarak, araştırmacılar için bazı öneriler sunulmaya çalışılacaktır.

\section{2. ÖLÇEKLERIN FARKLI DÍLLERE UYARLANMASI VE KÜLTÜRLERARASI KULLANIMINA YÖNELIKK YÖNLENDİRICİ ILLKELER}

Ölçeklerin uyarlanması ve kültürlerarası kullanımı ile ilgili olarak, ITC tarafindan 1993 yılında 22 maddeden oluşan yönlendirici ilkeler belirlenmiştir (Hambleton, 1993, 1996, 2005; Hambleton \& de Jong, 2003; International Test Commission, 2005; Van de Vijver, 2001; Van de Vijver \& Hambleton, 1996). Yönlendirici ilke; ölçeklerin farklı dillerdeki kullanımı için, ölçek uyarlama çalışmasının değerlendirilmesi ya da paralel olarak farklı diller için ölçek geliştirilmesine yönelik uygulama olarak tanımlanmıştır (Hambleton, 1996). ITC yönlendirici ilkeleri; aşağıdaki başlıklar altında tasnif edilmiştir (Hambleton \& de Jong; 2003; International Test Commission, 2005; Van de Vijver \& Hambleton, 1996; Van de Vijver \& Leung, 1997a). 
Tablo 1: Yanll1ık Çeşitleri ve Kaynakları

\begin{tabular}{|c|c|}
\hline Yanlılık Türü & Yanlılık Kaynakları \\
\hline \multirow{4}{*}{ Yap1 Yanllilğ́1 } & - İncelenen yapının tanımlanmasında kültürlerarasında ötüşmenin tam olmamas1 \\
\hline & •İncelenen yapı ile ilgili davranışların farklılaşan uygunluk düzeyleri \\
\hline & $\begin{array}{l}\text { - İncelenen yapı ile ilgili olarak incelenen davranış örnekleminin uygunluğunun düşük } \\
\text { olması }\end{array}$ \\
\hline & - İncelenen yapının boyutlarının yetersiz derecede kapsanması \\
\hline \multirow{6}{*}{ Yöntem Yanllilığ1 } & - Farklilaşan sosyal beğenilirlik düzeyi \\
\hline & $\begin{array}{l}\text { - Farklilaşan cevap verme tarzları (uç noktalarda cevaplar verme, olumlu cevaplara yönelme, } \\
\text { vb.) }\end{array}$ \\
\hline & - Yapiya farklılaşan aşinalık derecesi \\
\hline & • Ölçek uygulama koşullarında fiziksel farklılaşma \\
\hline & - Cevap verme prosedürlerine yönelik farklılaşan aşinalık derecesi \\
\hline & - Ölçek talimatlarının muğlak olması \\
\hline \multirow{4}{*}{ Madde Yanliliğ1 } & - Uygun olmayan madde çevirisi ya da muğlak maddeler \\
\hline & - Soru maddesinin farklı ya da ilave özellik ve yetenekleri uyarması \\
\hline & • Karmaşık cümlelerin mevcudiyeti \\
\hline & - Madde içeriğinin uygunluğunda farklilıkların mevcudiyeti \\
\hline
\end{tabular}

Kaynak: Van de Vijver \& Tanzer (2004), Van de Vijver \& Poortinga (1997)

- Ölçek içeriği (2 madde): Yapı, yöntem ve madde yanlılığını azaltma ve yapı benzerliğini değerlendirmeye yönelik yönlendirici ilkeler,

- Ölçek geliştirme ve uyarlama (10 madde): Ölçek geliştirme ve uyarlama sürecine yönelik yönlendirici ilkeler,

- Ölçek uygulama (6 madde): Yöntem yanlılığını azaltmaya yönelik yönlendirici ilkeler,

- Ölçeklerden elde edilen verileri yorumlama (4 madde): Yorumlama ve kültürleraras1 karşılaştırmaya yönelik yönlendirici ilkeler.

\section{YANLILIK VE DENKLIKK}

Yanlılık; ölçeklerin denkliğine olumsuz yönde etki ederek ölçek çevirilerinin uygunluk düzeyini azaltır (Ægisdóttir vd., 2008; Van de Vijver \& Hambleton, 1996) ve kültürlerarası karşılaştırılabilirlik ile ölçek skorlarının skalar denkliğini kısıtlar (Ægisdóttir vd., 2008). Ölçülen yapıya ait göstergelerdeki skor farklılıkları ile ölçülen yapının altında yatan özellik ve yeteneklere ait skor farkl1lkklarının birbiriyle örtüşmemesi halinde yanlılık oluşur (Van de Vijver \& Tanzer, 2004). Yanlılık; yapı yanlılığı, yöntem yanlılığ 1 ve madde yanlılığı olmak üzere üç şekilde ortaya çıkabilir (Ægisdóttir vd., 2008; Van de
Vijver \& Hambleton, 1996; Van de Vijver \& Tanzer, 2004).

Yap1 yanlılı̆ğ; ölçeğin ölçtüğü yapıların kültürlerarasında farklı olması, kültürlerarasında hem kavramsal hem de davranışsal olarak ihmal edilemeyecek derecede farklılıkların bulunması durumudur (Van de Vijver \& Hambleton, 1996). ITC'nin ölçek içeriğine yönelik yol gösterici ilkelerinden ikincisi; ölçme konusu olan yapılardaki kültürlerarası örtüşmenin miktarının varsayılması yerine, değerlendirmeye tabi tutulması gerektiğini vurgulamaktadır (Hambleton, 1996; International Test Commission, 2005; Van de Vijver \& Hambleton, 1996).

Bir araştırmada; metodoloji ve süreç yönlerinden kaynaklanan her türlü yanlılık, yöntem yanlılığ 1 olarak nitelendirilmektedir (Van de Vijver, 1998). Yöntem yanlılığı; ölçülen yapı ile ilgili olmayan bir kültürel faktörün, ölçeğin birçok maddesini veya ölçeğin tamamını farklı yönde etkilemesi olarak tanımlanmakta (Van de Vijver \& Poortinga, 1997) ve ölçeklerin uygulanması ile ilgili faktörler olan ölçeği katılımcılara uygulama farklılıkları, katılımcıların sosyal beğenilirlik düzeylerinde farklılaşma, katılımcıların ölçek ile farklılaşan aşinalık dereceleri ile ilişkilendirilmektedir (Ægisdóttir vd., 2008; Van de Vijver \& Hambleton, 1996). ITC'nin ölçek çevirisine yönelik yol gösterici ilkelerinden üçüncüsü; ölçek uygulanacak hedef kitlenin tamamının aşina olduğu ölçme 
teknikleri ve ölçek madde formatlarının seçilmesinin gerekli olduğunu belirtmektedir (Hambleton, 1996; International Test Commission, 2005; Van de Vijver \& Hambleton, 1996).

Madde yanlılığ 1 ise; ölçek maddeleri düzeyinde yanlılık ve bozulma olup (Ægisdóttir vd., 2008; Van de Vijver \& Tanzer, 2004); noksan ifadelerin kullanılması, belirli bir kültürel grup için madde içeriğinin uygun olmaması ve yanlış çeviri gibi ölçek maddesi anormalliklerine işaret etmektedir (Van de Vijver \& Hambleton, 1996). ITC'nin ölçek içeriğine yönelik yol gösterici ilkelerinden birincisi; çalışmanın ana amacı bakımından önemli olmayan kültürel farklılıkların etkisinin mümkün olduğunca azaltılması gerektiğini belirtmektedir (Hambleton, 1996; International Test Commission, 2005; Van de Vijver \& Hambleton, 1996). Bu ilke; yapı yanlılığı, yöntem yanlılığı ve madde yanlılığının mümkün olduğunca asgariye indirilmesi gerektiğini ifade etmektedir (Hambleton, 1996).

Yanlılık ile birlikte değerlendirmeye alınan ölçekler arası denklik; bir ölçeğin farklı dillerdeki (orijinal ölçek ve uyarlanmış ölçek/ölçekler) versiyonlarından elde edilen verilerin karşılaştırılabilir olmasıdır (Hambleton, 1993). Denklik; dört farklı şekilde ve hiyerarşik bir sıra ile (yapısal denk olmama, yapı denkliği, ölçüm birimi denkliği ve skalar denklik) tasnif edilmektedir (Van de Vijver, 1998, 2001). Yapısal denk olmama; ölçülen yapılar arasında hiçbir şekilde bağlantı olmamas1 (Ægisdóttir vd., 2008) ve bir ölçeğin farklı kültürlerde farklı yapıları ölçüyor olmasıdır (Van de Vijver \& Tanzer, 2004). Ciddi seviyede yapı yanlılığının mevcudiyeti, yapısal denk olmama durumuna yol açabilmektedir (Ægisdóttir vd., 2008).

Yapı denkliği; bir ölçeğin farklı kültürlerde aynı yapıyı ölçmesi durumudur (Van de Vijver \& Tanzer, 2004). Yapı denkliğinde; yapılar, aynı anlama gelmekte ve aynı nomolojik ağa (nomological network) sahip olmaktadır; ancak yapıların her kültürde aynı şekilde işletimselleştirilmesi (operationalization) gerekli değildir (Ægisdóttir vd., 2008). Diğer yandan; yapısal olarak denk olma, ölçek maddesi bazında denkliğin mevcudiyeti anlamına gelmemektedir (Zumbo, 2003).

Ölçüm birimi denkliği; ölçek skalalarının aynı olması, ancak köken/orijinlerinin gruplar arasında farklı olması durumudur (Ægisdóttir vd., 2008). Örneğin uzunluk birimi olarak metre ve mil aralıklı yapıdadır ancak kökenleri farklı olduğundan örneğin 25 metre 25 mile eşit değildir ve uzunluk olarak mil ve metre doğrudan karşılaştırılamaz (He \& Van de Vijver, 2012). Ancak, iki ölçeğin orijinleri arasındaki fark sabit ve biliniyor ise birbirine dönüştürülmek suretiyle ölçeklerden elde edilen skorlar karşılaştırılabilir (Van de Vijver \& Tanzer, 2004).

Skalar denklik; en yüksek seviyede denklik olup hem ölçeklerin skalalarının ve hem de kökenlerinin gruplar arasında aynı olması (Ægisdóttir vd., 2008) ve ölçeklerden elde edilen skorlarda hiçbir şekilde yanlılığın söz konusu olmaması (Van de Vijver \& Tanzer, 2004) durumudur. Skalar denklik halinde; farklı kültürlerden elde edilmiş olan veriler doğrudan karşılaştırılabilir.

Yapı denkliğini sağlamak için yapı yanlılığı ortadan kaldırılmalıdır. Diğer yandan, yöntem ve madde yanlılığ1 yap1 denkliğine etki etmez, ancak ölçüm birimi denkliği ve skalar denkliği tehlikeye sokabilir (He \& Van de Vijver, 2012). Gruplar arası değerlendirmelerin de yapılabilmesi için yapı ve ölçüm birimi denkliğinin yanında skalar denkliğin de sağlanmış olması gerekir (Ægisdóttir vd., 2008). Örneğin, Çatışma Yönetimi Ölçeğinin (ROCI-II) orijinal hali olan İngilizce versiyonundan ve farklı bir dile uyarlanmış versiyonundan elde edilen verilerin birbiriyle karşılaştırılabilmesi için skalar denklik dâhil olmak üzere tüm denklik türlerinin sağlanmış olması gerekir. Dolayısıyla ölçeklerin her üç düzeyde (yapı, ölçüm birimi ve skalar) denkliği için bütün yanlılıkların bertaraf edilmiş olması gerekmektedir (Van de Vijver, 1998). Yanlılığa neden olan kaynaklar bilindiği takdirde; yanlılığın ne derece mevcut olabileceği ve denkliği ne derece tehdit edebileceği de ortaya konulabilir. Tablo-1'de yanlılık kaynakları ve hangi çeşit yanlılığa neden oldukları; Tablo-2'de ise yanlılığın üstesinden gelme stratejileri verilmiştir.

\section{BİR ÖLÇEĞİN BAŞKA BİR DİLE UYARLANMASINA YÖNELIKK HUSUSLAR}

Ölçeklerin uyarlanmasında; orijinal dildeki ölçeğe denkliği sağlamak amacıyla, hem öznel değerlendirmeler hem de nesnel değerlendirmeler yapılmalıdır (Hambleton, 1993). Çevirinin uygunluğu; sadece çeviri ve geri-çeviri süreçleri gibi öznel değerlendirmelerle sınırlı kalmamalı ve istatistikî değerlendirmelerle de desteklenmelidir (Van de Vijver \& Hambleton, 1996). Bu nedenle; ölçek uyarlamasına yönelik hususlar tartışılırken; öznel değerlendirmeleri içeren çeviri, geri-çeviri ve ön test adımlarına ek olarak Açımlayıcı Faktör Analizi (AFA) ve Doğrulayıcı Faktör Analizi (DFA) vb. nesnel yöntemlere de yer verilmelidir. Ölçek uyarlamasına ilişkin hususlar; (a) ölçek geliştirme çalışması ya da ölçek uyarlama çalışmasından hangisinin yapılacağına karar 
Tablo 2: Yanllilığ Teşhis Etme ve Yanlilığın Üstesinden Gelme Stratejileri

\begin{tabular}{|c|c|}
\hline Yanlllık Türü & Yanlılığın Üstesinden Gelme için Stratejiler \\
\hline \multirow[b]{2}{*}{ Yap1 Yanl1lı̆̆1 } & • Merkezsizleştirme (decentering) \\
\hline & $\begin{array}{l}\text { - Birleşim yaklaşımı (convergence apporoach) (her iki versiyonun karşılaştırılacak her iki } \\
\text { gruba uygulanması) }\end{array}$ \\
\hline \multirow{4}{*}{ 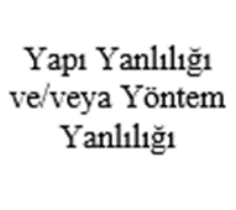 } & - Kültür ve dil ile ilgili uzmanlığa sahip kişilerden istifade etme \\
\hline & • Her iki dili bilen örneklem kullanma \\
\hline & - Standart olmayan test uygulama yöntemlerini tatbik etme (örneğin; sesli düşünme) \\
\hline & • Nomolojik ağların kültürlerarası karşılaştırmasını yapma \\
\hline \multirow{5}{*}{$\begin{array}{l}\text { Yöntem } \\
\text { Yanllilğg1 }\end{array}$} & - Ölçek uygulayan kişilerin eğitimi \\
\hline & - Uygulama, derecelendirme ve yorumlama konusunda ayrintili talimatlar oluşturma \\
\hline & • Kontrol değişkenleri kullanma \\
\hline & - Cevap verme stillerinin değerlendirilmesi \\
\hline & - Test-tekrar uygulanmasi \\
\hline \multirow{2}{*}{ Madde Yanllilğg } & - Madde yanll1ı̆ğını ortaya koyacak öznel değerlendirmeler yapma \\
\hline & - Psikometrik yöntemler uygulama \\
\hline
\end{tabular}

Kaynak: He \& Van de Vijver (2012), Van de Vijver \& Tanzer (2004)

verilmesi, (b) ölçeğin hedef dile çevrilmesi, (c) hedef dile çevrilen ölçeğin hedef dilden ölçeğin orijinal diline geri-çevrilmesi, (d) uzman/hakem görüşüne başvurulması, (e) ön test yapılması, (f) ölçeğin güvenilirliğinin değerlendirilmesi, (g) ölçeğin geçerliliğinin değerlendirilmesi ve (h) ölçeğin yanlılığının/denkliğinin değerlendirilmesi başlıkları altında incelenebilir.

\section{1. Ölçek Geliştirme Çalışması ya da Ölçek Uyarlama Çalışmasından Hangisinin Yapılacağına Karar Verilmesi}

Yönetim ve örgüt araştırmalarında kültürel göreceliğe dikkat çeken araştırmalar (Hofstede, 1980; House, Hanges, Javidan, Dorfman \& Gupta, 2004; Triandis, 1995); ABD kaynaklı yönetim modellerinin ve kavramlarının farklı kültürel bağlamlar için geçerliliklerinin sorgulanmasına hız kazandırmıştır (Gürbüz, 2015). Bu noktada etikemik yaklaşım ayrımı ön plana çıkmaktadır. İnceleme konusu olan olguya dişarıdan bakışı ifade eden etik yaklaşım, ilgili yapının evrensel olduğunu ve tüm kültürlerde aynı olduğunu varsayarken; içeriden bakış açısını ifade eden emik yaklaşım ise söz konusu olgunun tüm kültürlerde aynı olamayacağını savunmaktadır (Sargut, 2010). Emik yaklaşımı tercih edenler, diğer kültürlerde geliştirilmiş ölçekleri kullanmak yerine bahse konu kültüre yönelik bir ölçek geliştirme çabasına girmekte; etik yaklaşımı tercih edenler ise incelenen olguların kültürlerarasında benzer oldukları savından hareketle ölçeklerin birebir çevirisi ya da diğer kültüre/dile uyarlanması yoluna gidilebileceğini benimsemektedirler (Ægisdóttir vd., 2008). Burada önemli olan yap1 denkliğine karar verilmesidir. Eğer incelenen yap1, ölçeğin geliştirildiği kültür ile ölçeğin uyarlanacağı kültür arasında denklik göstermiyor ise ölçek uyarlama çalışmasına devam edilmemelidir (Hambleton \& Patsula, 1999). Hambleton ve Patsula (1999); her iki dile ve kültüre aşina olan araştırmacıların kültürlerarası yap1 denkliğinin mevcut olup olmadığına karar verebileceklerini dile getirmekte; ve hatta herhangi bir kişinin her iki kültürden bireylerle mülakat yaparak, onları gözlemleyerek, her iki kültür hakkında araştırma yaparak, bahse konu kültürleri bilen kişilere danışarak incelenecek olan olgunun iki kültür arasında denkliğe sahip olup olmadığına kanaat getirebileceğini belirtmektedir. İncelenen olguların/yapıların kültürlerarası benzer olduğuna kanaat getirilmesi, farklı bir dilde geliştirilmiş olan mevcut bir ölçeğin hedef dile uyarlanması yani ölçek uyarlama çalışması yapılabileceği anlamına gelmektedir.

Ölçek uyarlama çalışmasına karar verildi ise, ölçeği geliştiren araştırmacı(lar)dan izin almanın gerekli olup olmadığı sorusu gündeme gelmektedir. İzin almanın etik olarak mutlaka gerekli olduğunu belirten Deniz'in (2007) aksine American Psychological Association (2010) "Etik, Kanuni ve İlkesel Gerekliliklere Uyma" başlığı altında; Minnesota Çok Aşamalı Kişilik Envanteri (Minnesota Multiphasic Personality Inventory) gibi "sadece telif hakkı (copyright) ve ticari değeri olan" 
testler, ölçek maddeleri, anketler vb. için izin alınmasının gerekli olduğu belirtilmektedir. $\mathrm{Bu}$ noktadan hareketle bu özellikleri taşımayan ölçeklerin uyarlanması için izin alınmasına gerek olmadığı ifade edilebilir.

\section{2. Ölçeğin Hedef Dile Çevrilmesi}

ITC'nin ölçek geliştirme ve uyarlama sürecine yönelik yol gösterici ilkelerinden beşincisine göre; uyarlama sürecinin doğruluğunu yükseltmek amacıyla, sistematik olarak hem dilbilimsel hem de psikolojik olarak öznel değerlendirme uygulanmalı ve ölçeğin değişik dillerdeki versiyonlarının denkliğini kanıtlamak için veriler ortaya konulmalıdır (Hambleton, 1996; International Test Commission, 2005; Van de Vijver \& Hambleton, 1996). Çevirinin denkliğini kontrol etmek amacıyla; ölçek uygulanmadan ve istatistiksel yöntemler tatbik edilmeden önce, çeviri ve geri-çeviri olarak adlandırılan öznel yöntemler uygulanmalıdır (Hambleton, 1996).

Brislin vd. (1973); çeviri amacıyla, tek kişinin kullanılabileceğini ya da bir komisyon oluşturulabileceğini belirtmektedirler. Ancak, ITC'nin ölçek geliştirme ve uyarlama sürecine yönelik yol gösterici ilkelerinden "çevirilerin doğruluğunu artırmak için sistematik olarak hem dilbilimsel hem de psikolojik öznel değerlendirmelerin uygulanmasını gerektiren" beşincisinin gereklerini karşılayabilmek için; çevirilerde, tek kişi yerine bir grubun oluşturulması önerilmektedir (International Test Commission, 2005:7; Van de Vijver \& Hambleton, 1996:94). Çevirilerde komisyon oluşturulması, tek kişiden oluşabilecek yanlılıkları ve yanlış anlamaları azaltabilmektedir (Ægisdóttir vd., 2008; Hambleton, 2005; Hambleton \& Patsula, 1999).

ITC'nin ölçek geliştirme ve uyarlama sürecine yönelik yol gösterici ilkelerinden birincisi; orijinal dil ve çevrilen dil için, çeviri sürecinin hem dilbilimsel hem de kültürel farklılıkların tamamını dikkate alması gerektiğini vurgulamaktadır (Hambleton, 1996; International Test Commission, 2005; Van de Vijver \& Hambleton, 1996). Uyarlama çalışmalarının, kaynak dil ile hedef dilin her ikisini de bilen herhangi bir kişinin gerçekleştirebileceği rutin bir süreç olarak görülmesi, kaynak dile denkliği sadece yüzeysel olarak sağlanmış olan uyarlanmış ölçüm araçlarının ortaya çıkmasına neden olmaktadır (Hambleton \& Patsula, 1999). Bu nedenle; komisyon üyeleri, her iki dile, her iki kültüre, ölçülen yapıya, temel psikometri bilimine vâkıf, ölçek geliştirme becerisi olan ve çevrilen ölçme aracının amacını bilen kişilerden oluşturulmalıdır (Ægisdóttir vd., 2008; Hambleton, 1993; Hambleton \& Patsula, 1999; Van de Vijver \& Hambleton, 1996). Özellikle farklı alanlarda uzmanlığa (kültür, dilbilim, psikoloji, vb.) sahip üyelerin oluşturduğu komisyonlarda, çevirilerin kalitesini artıran müşterek çabaların mevcudiyeti komisyon yaklaşımının en güçlü yanını oluşturmaktadır (Van de Vijver \& Tanzer, 2004). Çeviri yapan kişilerin farklı konularda bilgi sahibi olması, doğrudan çevirilerden kaynaklanan madde yanlılığını da azaltmaktadır (Ægisdóttir vd., 2008).

Komisyon üyeleri, çeviri esnasında birbiri ile etkileşime girmeden, bireysel ve birbirlerinden bağımsız olarak çevirilerini yapmalıdırlar (Ægisdóttir vd., 2008). Ölçeklerden elde edilen verilerin geçerli olabilmesi için, orijinal dildeki ölçeğin maddelerindeki ve talimatlarındaki anlamın korunması yönünde gayret sarf edilmelidir (Hambleton, 1993). Bireysel çevirilerin ardından tüm üyelerin çevirileri ortaya konulmalı ve en optimal çeviri üzerinde karara varılana kadar çevirilerin karşılaştırılmasına devam edilmelidir (Ægisdóttir vd., 2008). Hedef dile çevrilen ölçek; hedef dilin gramer yapısına en iyi şekilde uyumunu sağlamak için gerekiyorsa tekrar yazılmalıdır (Ægisdóttir vd., 2008).

\subsection{Hedef Dile Çevrilen Ölçeğin Hedef Dilden Orijinal Diline Geri-Çevrilmesi}

Bir ölçeğin kaynak dilden başka bir dile basit ve tek yönlü olarak çevirisinin kabul edilemez olduğu açık bir gerçektir (Johnson, 1998). Bu nedenle geriçeviri yöntemi (Brislin, 1970, 1976, 1986) kullanılmaktadır. Geri-çeviri; orijinal ölçeğin hedef dile çevrilmiş haline daha ileri bir seviyede iyileştirme yapılmasına ve ölçeklerin denkliğinin sağlanmasına yardımcı olur (Ægisdóttir vd., 2008). Mallinckrodt ve Wang (2004) ise; geri-çevirinin, çevrilmiş olan bir ölçeğin orijinal haline semantik denkliğinin (orijinal ölçek maddelerinin anlamlarının çeviri sürecinde hedef dildeki ölçeğe taşınması) doğrulanması amacıyla kullanıldığını belirtmektedirler.

Geri-çeviri, orijinal dildeki ölçeği hedef dile çeviren komisyondan farklı bir komisyon tarafindan yapılmalı (Ægisdóttir vd., 2008), bu komisyon orijinal dildeki ölçeği görmüş ya da biliyor olmamalıdır (Mallinckrodt \& Wang, 2004). Komisyon üyeleri, geri-çeviri esnasında birbiri ile etkileşime girmeden, bireysel ve birbirlerinden bağımsız olarak çevirilerini yapmalıdırlar (Ægisdóttir vd., 2008).

\subsection{Uzman / Hakem Görüşüne Başvurulması}

Uzmanlardan oluşan bir hakem grubu; ölçeğin orijinal hali ile geri-çevrilmiş halini, madde madde ilerleyerek, talimat kısmı da dâhil olmak üzere 
karşılaştırarak, dilbilimsel olarak en uygun geriçeviri hakkında ortak bir karar vermelidir (Ægisdóttir vd., 2008; Hambleton, 2005; Mallinckrodt \& Wang, 2004). Ölçeğin orijinal hali ile geri-çevrilmiş hali arasında benzerlik bulunmuyorsa; komisyonlar (çeviri komisyonu ve geri-çeviri komisyonu), denklik sağlanana kadar ölçeğin çevirisi üzerinde çalışmalıdırlar (Ægisdóttir vd., 2008).

Çeviri ve geri-çevirinin denk hale getirilmesi ile ilgili olarak; bu aşamada, (a) ölçeğin sadece çevrilen dilde kullanılarak bir çalışma yapılması ya da (b) ölçeğin hem orijinal dilde hem de çevrilen dilde kullanılarak iki kültür arasında karşılaştırma yapılmasına yönelik bir çalışma yapılması şeklinde iki farklı seçenek ortaya çıkmaktadır. Sadece çevrilen dilde çalışma yapılacak ise geri-çevirinin orijinal ölçeğe denkliği sağlanana kadar çeviri işlemine devam edilir. Eğer kültürlerarası bir karşılaştırma yapılması hedefleniyorsa çeviri ve geri-çeviri bir sarmal şeklinde her ikisi birbirine denk olana kadar çeviri ve geri-çeviri sürecine devam edilir. $\mathrm{Bu}$ süreç ilk olarak Werner ve Campbell (1970) tarafindan ortaya atılan merkezsizleştirme (decentering) olarak tanımlanmaktadır (Brislin, 1986). Merkezsizleştirme; orijinal ölçeğin ve çevrilmiş ölçeğin her ikisine de eşit derecede önem verildiği ve her iki ölçeğin de değişiklik yapmaya açık olduğu bir çeviri ve geri-çeviri sürecidir (Ægisdóttir vd., 2008). Burada amaç; çevrilmiş ölçeğin orijinal haline denk olması değil, çeviri ve geri-çevirinin artık değişkenlik göstermeyecek şekilde birbirine denk olmasıdır. Kültürlerarası karşılaştırma yapılacak ise; orijinal ölçek yerine geri-çevrilmiş ölçeğin kullanılması önerilmektedir (Brislin, 1986).

\section{5. Ön Test Yapılması}

Çeviri-geri çeviri sürecinin ardından, uygulamada kendisinden beklenen işlevi iyi bir şekilde yerine getiremeyebilecek bazı maddelerin halen var olabileceği düşüncesiyle, ön test yapılmak suretiyle ölçek test edilmelidir (Brislin, 1986; Hambleton \& Patsula, 1999). ITC'nin ölçek geliştirme ve uyarlama sürecine yönelik yol gösterici ilkelerinden altıncısına göre; veri toplama tasarımı, ölçeğin farklı dillerdeki versiyonları arasında ölçek maddelerinin denkliğini ortaya koyabilmek amacıyla uygulanacak istatistiksel tekniklerin tatbikine müsaade etmesi gerekmektedir (Hambleton, 1996; International Test Commission, 2005; Van de Vijver \& Hambleton, 1996). Ölçeği denemek amacıyla yapılacak ön test çalışmasında, ITC tarafindan ortaya konulan bu gerekliliği karşılayacak şekilde üç farklı yaklaşım uygulanabilir.
- Her iki dili bilen bir örneklem grubuna hem orijinal hem de çevrilmiş olan ölçeğin uygulanması (Brislin vd., 1973; Van de Vijver \& Hambleton, 1996). Bu yöntemde; her iki dildeki ölçeklerin uygulandığı örneklemlerin farklılık yaratabilecek özellikleri kontrol altına alınabilmekte (Hambleton, 1996) ve ölçeğin iki farklı dildeki versiyonlarından elde edilen skorlardaki farklılıklar, örneklem farklılığı değil de çeviriden kaynaklanan farklılıklara atfedilebilmektedir (Van de Vijver \& Hambleton, 1996). Hem orijinal ölçeğin hem de çevrilmiş olan ölçeğin her iki dili bilen bir örneklem grubuna uygulanmasının ardından, ölçeğin iki dildeki versiyonlarına aynı kişiler tarafından verilen yanıtlar istatistik yöntemlerle (örneğin t-testi) karşılaştırılır. Karşılaştırma sonucunda farklılıklar tespit edilir ise çeviriler gözden geçirilerek gerekli düzeltmeler yapılır.

- Çevrilmiş ölçeğin küçük bir gruba uygulanması ve sözlülyazılı geri bildirim alınması (Ægisdóttir vd., 2008). Brislin vd. (1973); geri bildirim almak amaciyla, "rastgele sorgulama" ve "ölçek maddelerinin bir ölçeğe göre değerlendirilmesi" şeklinde iki yöntem uygulanabileceğini belirtmiştir. Rastgele sorgulama yönteminde; ölçekten rastgele seçilen maddeler ile ilgili olarak katılımcılara bu maddelerin ne anlama geldiği sorulur (Schuman, 1966). Uygun olmayan ve tuhaf cevaplar alınan maddeler incelemeye alınarak çevirileri değiştirilir. $\mathrm{Bu}$ yöntem; çeviri sonucu elde edilmiş bir ölçekte, orijinal ölçek maddelerinin ne kadar başarılı bir şekilde temsil edildiğine yönelik bilgi alınmasını sağlar (Ægisdóttir vd., 2008). Ölçek maddelerinin bir ölçeğe göre değerlendirilmesi yönteminde ise; ölçek maddeleri anlaşılırlık ve uygunluk bakımından katılımcılar tarafından değerlendirilerek katılımcıların ölçeğe yönelik açıklık ve uygunluk algıları elde edilir. Açık ve uygun olmayan ölçek maddeleri, başka kelimelerle ifade edilecek şekilde değiştirilir.

- Odak grup çalışması (Ægisdóttir, Gerstein \& Gridley, 2000). Ölçeğin hedef dile çevrilmiş hali bir gruba uygulanır. Her maddeye katılımciların ne anlam yüklediği araştırmacının da katılımı ile grup şeklinde tartışılır. Ayrıca katılımcılar ölçeğin açıklığg ve kültüre uygunluğu hakkındaki algılarını araştırmacı ile paylaşırlar. Odak grup çalışmasından elde edilen veriler doğrultusunda maddelerin ifade ediliş şekilleri değiştirilir.

\section{6. Ölçeğin Güvenilirliğinin Değerlendirilmesi}

Ölçek uyarlama çalışmalarında; ön test uygulamasının ardından ölçeğin güvenilirliğinin değerlendirilmesine yönelik analizler yapılmalıdır (Ægisdóttir vd., 2008; Hambleton \& Patsula, 1999). Ölçeğin tutarlı ölçüm yapıp yapmadığı ya da ölçek 
maddeleri arasında tutarlılık olup olmadığının belirlenmesi amacıyla kullanılan analiz güvenilirlik analizidir ve bu amaçla iç tutarlılık güvenilirliği, test-tekrar güvenilirliği, paralel formlar güvenilirliği ile yarıya bölme güvenilirliği (split-half reliability) şeklinde farklı yöntemler kullanılmaktadır (DeVellis, 2003; Gürbüz \& Şahin, 2015).

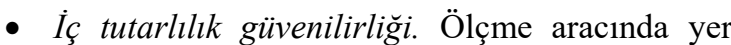
alan maddelerin kendi aralarında tutarlılık gösterip göstermediğini test etmek amacıyla uygulanır. Eğer bir ölçeğin maddelerinin ilgili oldukları örtük değișken ile güçlü ilişkileri var ise, bu maddelerin birbirleri ile de güçlü ilişkilere sahip olmaları beklenir (DeVellis, 2003). İç tutarlılık güvenilirliğinin tespiti; Cronbach Alpha değerinin hesaplanmas1, madde-toplam puan korelasyon analizi, maddeler arası korelasyon analizi, iki şıklı değerlere ait korelasyon analizi gibi farklı hesaplama ve istatistiksel yöntemlerle yapılabilmektedir (Ægisdóttir vd., 2008; Gürbüz \& Şahin, 2015). Cronbach Alpha değerinin hesaplanması, iç tutarlılığı ölçmek amacıyla kullanılan yaygın yöntemlerden biridir (DeVellis, 2003) ve maddeleri sürekli değişken değerler alan ölçekler için kullanılır. (Cronbach, 1951; Gürbüz \& Şahin, 2015). Madde-toplam puan korelasyon analizinde ise madde-toplam puan korelasyon katsayılarının ortalaması hesaplanarak ölçüm aracının güvenilirliği belirlenir (Gürbüz \& Şahin, 2015).
- Test-Tekrar Güvenilirliği. Bir ölçüm aracının aynı örneklem üzerinde farklı zamanlarda uygulanması halinde benzer sonuçlar vermesidir (Gürbüz \& Şahin, 2015). Farklı zamanlarda aynı örneklem üzerinde uygulanan ölçümlerden elde edilen sonuçlar arasındaki korelasyon katsayısı, o ölçüm aracının test-tekrar güvenilirlik katsayısıdır (DeVellis, 2003).

- Paralel Formlar Güvenilirliği. Bir ölçeğin iki defa uygulanmasının çeşitli nedenlerle mümkün olmadığ 1 durumlarda; paralel iki form geliștirilerek bu formlardan elde edilen sonuçlar arasındaki ilişkiye ait korelasyon değerinin hesaplanmasıyla paralel formlar güvenilirlik katsayısı elde edilir (Gürbüz \& Şahin, 2015).

- Yarlya Bölme Güvenilirliği. Bir ölçüm aracının maddeleri rastgele bir şekilde ikiye bölünür ve oluşturulmuş olan yarım ölçeklerin her ikisi de aynı örnekleme uygulanır (DeVellis, 2003). Her bir katılımcının iki yarım ölçekten elde ettiği sonuçlar arasındaki korelasyon katsayısı, yarıya bölme güvenilirlik düzeyini gösterir (Field, 2009).

\section{7. Ölçeğin Geçerliliğinin Değerlendirilmesi}

Ölçek uyarlama çalışmalarında; ölçeğin güvenilirliği ile birlikte geçerliliğinin de değerlendirilmesine yönelik analizler yapılmalıdır

Tablo 3: Geçerlilik Türleri

\begin{tabular}{|c|c|}
\hline $\begin{array}{l}\text { Görünüş Geçerliliği } \\
\text { (Face Validity) }\end{array}$ & $\begin{array}{l}\text { Bir ölçüm aracının ölçülmek istenen yapıyı ölçebildiğine yönelik olarak görünüyor } \\
\text { olmasının derecesidir. }\end{array}$ \\
\hline $\begin{array}{l}\text { İçerik Geçerliliği } \\
\text { (Content Validity) }\end{array}$ & $\begin{array}{l}\text { Ölçülmesi amaçlanan kavramı, ölçüm aracında yer alan maddelerin ne ölçüde temsil } \\
\text { ettiğinin göstergesidir. }\end{array}$ \\
\hline $\begin{array}{l}\text { Ölçüte Dayalı } \\
\text { Geçerlilik } \\
\text { (Criterion Validity) }\end{array}$ & $\begin{array}{l}\text { Ölçüm aracının etkinliğinin belirlenmesi amacıyla, ölçüm aracından elde edilen } \\
\text { puanlarla belirlenen kriter arasında gelecekteki veya o andaki ilişkinin seviyesidir. } \\
\text { Ölçüm aracı ile belirlenen kriter arasındaki korelasyon katsayısına göre geçerlilik } \\
\text { seviyesi hakkında çıkarım yapılır. Yordama/tahmin geçerliliği (predictive validity) } \\
\text { ve eşzaman geçerliliği (concurrent validity) olmak üzere iki alt kategorisi mevcuttur. }\end{array}$ \\
\hline $\begin{array}{l}\text { Yap1 Geçerliliği } \\
\text { (Construct Validity) }\end{array}$ & $\begin{array}{l}\text { Araştırma için ele alınan kavramsal yapının tam olarak açı̆ga çıkartılma derecesinin } \\
\text { göstergesidir. Birleşim geçerliliği (convergent validity), ayrışım geçerliliği } \\
\text { (discriminant validity) ve tek/çok boyutluluk olmak üzere üç alt kategorisi } \\
\text { mevcuttur. }\end{array}$ \\
\hline $\begin{array}{c}\text { İç Geçerlilik } \\
\text { (Internal Validity) }\end{array}$ & $\begin{array}{l}\text { Bağımlı değişkendeki değişimin gerçekten bağımsız değişkenden kaynaklanma } \\
\text { derecesinin göstergesidir. }\end{array}$ \\
\hline $\begin{array}{l}\text { Diş Geçerlilik } \\
\text { (External Validity) }\end{array}$ & $\begin{array}{l}\text { Bir ölçüm sonucunun, diğer olay, kişi ve bağlamlara genellenebilme düzeyinin } \\
\text { göstergesidir. }\end{array}$ \\
\hline
\end{tabular}

Kaynak: Gürbüz \& Şahin'den (2015) yararlanılarak geliştirilmiştir. 
(Ægisdóttir vd., 2008; Hambleton \& Patsula, 1999). ITC'nin ölçek geliştirme ve uyarlama sürecine yönelik yol gösterici ilkelerinden sekizincisine göre; uyarlama sonucu elde edilen ölçeklerin geçerliliğinin değerlendirilmesine yönelik veriler ortaya konulmalıdır (Hambleton, 1996; International Test Commission, 2005; Van de Vijver \& Hambleton, 1996). Bir ölçüm aracının, geliştirilmiş olduğu kültürde/dilde mevcut olan geçerliliğinin (örneğin; yap1 geçerliliği, yordayıcı geçerlilik, vb.) diğer bir kültüre/dile transferinin; ölçme aracının çevrilmesi suretiyle kendiliğinden gerçekleşmiş olacağ ölçüm aracının hedef kültürdeki/dildeki geçerliliği ayrıca ispatlanmalıdır (Van de Vijver \& Hambleton, 1996). Sosyal bilim araştırmalarında en çok kullanılan geçerlilik türleri ve tanımlamalar Tablo3'te sunulmuştur.

ITC'nin ölçek geliştirme ve uyarlama sürecine yönelik yol gösterici ilkelerinden onuncusuna göre; bir ölçeğin her kültür için uygun olmayan maddelerinin kültürlerarası karşılaştırmalarda kullanılmasından ziyade; bu maddeler, geçerli oldukları kültürler için bahse konu ölçeğin içerik geçerliliğini artırmada kullanılmalıdır (International Test Commission, 2005). Geçerlilik ile ilgili dikkat edilmesi gereken diğer bir husus; ölçek uyarlama çalışmalarında ölçek çevirilerinin uygun bir şekilde yapılmamasının, bu ölçekler ile veri toplayacak olan çalışmaların iç geçerliliklerine yönelik ciddi bir tehdit oluşturmakta olduğudur (Ægisdóttir vd., 2008). Ayrıca, bir ölçek uyarlama çalışması yapıldığında, yap1 geçerliliğinin mevcut olup olmadığına yönelik sorular da gündeme gelmektedir (Van de Vijver \& Poortinga, 2005). Emik yaklaşımı tercih ederek ölçeklerin farklı kültürlerde kullanılabileceğini kabul eden araştırmacılar, ölçeğin yapı geçerliliğinin (faktör analizi, yordama geçerliliği, benzeşim geçerliliğii, ayrışım geçerliliği, vb.) hedef kültürlerde mevcut olduğunu ispat etmelidirler (Ægisdóttir vd., 2008; Hambleton, 1996; Hambleton \& Patsula, 1999; Van de Vijver \& Tanzer, 2004). AFA ve DFA; ölçeğin yap1 geçerliliğini test etmede yaygın olarak kullanılan yöntemlerdir (Van de Vijver \& Poortinga, 2005). AFA; incelenen yapıya ait gözlenen değişkenlerin hangi faktörleri oluşturduğunu incelemek amaciyla uygulanır (Gürbüz \& Şahin, 2015). DFA ise incelenen kavramların veri tarafından doğrulanıp doğrulanmadığı, kuramsal evrende varsayılan ilişkilerin görgül gözlem sonucu elde edilmiş veri setinde de var olup olmadığını anlamaya çalışmak için uygulanır (Gürbüz \& Şahin, 2015). Ayrıca uyarlanan ölçeğin benzeşim, ayrışım ve yordama geçerliliklerine yönelik olarak yapılan analizler ölçeğin yap1 geçerliliğine yönelik kanıtları kuvvetlendirmektedir (Jex \& Britt, 2008).

\section{8. Ölçeğin Yanlılığının / Denkliğinin Değerlendirilmesi}

Kültürlerarası karşılaştırmalarda; bu çalışmalarda kullanılan ölçeklerin sadece geçerlilik ve güvenilirlikleri değil, aynı zamanda denkliklerinin de ispat edilmesinin genel bir uygulama haline geldiği belirtilmektedir (He \& Van de Vijver, 2012; Van de Vijver \& Tanzer, 2004). Bu nedenle kültürlerarası bir karşıllaştırma yapılacak ise yanlılık ve denklik ile ilgili hususlar analiz edilmeli ve yanlılığa neden olan faktörler giderilerek üç düzeyde de (yapı, ölçüm birimi ve skalar) denklik sağlanmalıdır.

- Yapr Yanlılı̆̆ı. Ölçeğin orijinal diline ait kültürde mevcut olan yapılar ölçeğin çevrildiği dile ait kültürde yok ise ya da farklı bir formda bulunuyor ise; çevrilen ölçekten elde edilecek olan veriler oldukça hatalı olacaktır (Hambleton, 1996). ITC'nin ölçek çevirisine yönelik yol gösterici ilkelerinden yedincisi; ölçeğin farklı dillerdeki versiyonlarının denkliğini ortaya koymak ve problem oluşturan içerik ve yönleri belirlemek amacıyla istatistik yöntemler uygulanmasinın gerekli olduğuna işaret etmektedir (Hambleton, 1996; International Test Commission, 2005; Van de Vijver \& Hambleton, 1996). AFA ve DFA, yap1 denkliğini ve dolayısıyla da yapı yanlılığını değerlendirmek amacıyla kullanılabilir (Ægisdóttir vd., 2008; Van de Vijver \& Hambleton, 1996). Ayrıca; yapı yanlılığını değerlendirmek amacıyla, Çok Boyutlu Ölçeklendirme (Multi Dimensional Scaling-MDS) ve Kümeleme Analizi (Cluster Analysis) de kullanılabilir (Ægisdóttir vd., 2008). Örneğin, MDS tekniğinde; ölçeklerin boyutları arasındaki göreli yakınlıklar incelenerek incelenen temel yapı tanımlanmaya çalışılır (Johnson, 1998).

- Yöntem Yanlılığı. ITC'nin ölçek uygulanmasına yönelik yol gösterici ilkelerinden üç ve dördüncüsünde; ölçek talimatlarının ve ölçeğin uygulandığ1 yerdeki çevresel faktörlerin, ölçekten elde edilen verilerde istenmeyen varyansa neden olması durumunun minimize edilmesi gerektiği belirtilmektedir (Hambleton, 1996; International Test Commission, 2005; Van de Vijver \& Hambleton, 1996). ITC'nin ölçekten elde edilen verilerin dokümantasyonu ve yorumlanmasına yönelik yol gösterici ilkelerinden dördüncüsü; ölçek ile ilgili olarak katılımcıların skorlarını etkileyen sosyo-kültürel ve çevresel faktörlerin neler olduğuna dair bilgiler sağlanmasının ve bu etkilerin azaltılmasına yönelik prosedürlerin ortaya konulmasının gerekliliğini vurgulamaktadır (Hambleton, 1996; Van de Vijver \& Hambleton, 1996). Bu ilkelerin yöntem yanlılığına ve bu yanlılığı azaltıcı tedbirlerin alınması gerektiğine işaret ettiği değerlendirilmektedir. Yöntem 
yanlılı̆̆ını tespit edebilmek amacıyla aşağıdaki ölçme yöntemleri kullanılabilir.

○ Madde-Genel Ölçek Korelasyonları: Ölçeğin toplam puanları ile her bir maddeye ait puanların korelasyonunun hesaplanması olup korelasyon katsayıs1 0,30'un altında olan maddelerin ölçekten çıkarılması önerilmektedir (Gürbüz \& Şahin, 2015).

- Kontrol değişkenlerinin uygulanması: Sosyal beğenilirlik (Ægisdóttir vd., 2008; Özen, 2000), tecrübeler, Kişi Başına GSMH (Ægisdóttir vd., 2008) ve sosyo-ekonomik statünün (Johnson, 1998) kontrol değişkenleri olarak ele alınıp kontrol altına alınması; ölçeklerden elde edilen skorların incelenen yapıdan kaynaklanmakta olduğuna yönelik kanaati daha da güçlendirecektir.

- Madde Yanlılığı. ITC'nin ölçek çevirisine yönelik yol gösterici ilkelerinden dokuzuncusu; ölçeğin çevrildiği dildeki maddelerinin orijinal ölçekteki maddelere denk olduğuna yönelik olarak istatistiksel kanıtlar ortaya konulmasının gerekli olduğuna işaret etmektedir (Hambleton, 1996; International Test Commission, 2005; Van de Vijver \& Hambleton, 1996). Madde yanlılığını ölçmede aşağıdaki yöntemler kullanılabilir.

- Madde skor dağılımları; yanlı maddeler ve dolayısıyla denklik hakkında bilgi sağlamaktadır (Ægisdóttir vd., 2008).

- Madde Tepki Kuramı (MTK; Item Response Theory-IRT) (Hambleton \& Swaminathan, 1985); madde yanlılığına dair veri elde edebilmek için en çok kullanılan yöntemlerden birisidir (Hambleton, 1996). MTK yönteminde; farklılaşan madde işlevi incelenmektedir. Madde karakteristik eğrisi; ölçülen değişken ile maddeye verilen yanıtlar arasındaki ilişkiyi gösteren diyagramdır (Ellis, 1989). Seçilen parametrelere (örneğin madde zorluğu, madde popülaritesi, vb.) göre madde karakteristik eğrileri ölçek uygulanan gruplar (yabanc1 dildeki versiyon ve hedef dil versiyonu uygulanan gruplar) arasında farklılaşıyorsa, bu farklılaşan maddelerin yanlı olduğuna kanaat getirilmektedir (Ægisdóttir vd., 2008; Van de Vijver \& Leung, 1997b).

- Madde yanlılığını değerlendirmek için varyans analizi (ANOVA) de kullanılabilir (Ægisdóttir vd., 2008). Üç aşamada yapılacak olan analizin ilk aşamasında; gruplara bakmaksızın tek boyuttan elde edilen skorlar hesaplanır. İkinci aşamada; aralıklarına göre toplam skorlar farklı seviyelere bölünür. Son aşamada ise; madde skoru bağımlı değişken olarak ve kültürel grup (yabancı dildeki versiyon ve hedef dildeki versiyonun uygulandığ 1 gruplar) ile skor seviyeleri ise bağımsız değişken olarak kabul edilerek ANOVA uygulanır. Kültür ve kültür ile skor değeri etkileşiminin madde skoru üzerinde istatistiki olarak anlamlı etkisinin tespit edilmesi halinde ilgili maddenin yanlılı̆̆ına kanaat getirilmektedir (He \& Van de Vijver, 2012)

- Ikili Dil Yarlya Bölme (Dual Language Split Half - DLSH). DLSH; Mallinckrodt ve Wang (2004) tarafindan yarıya bölme yönteminin kapsamının genişletilmesi suretiyle geliştirilmiş ve ölçeklerin denkliğinin tespitinde kullanılan farklı bir yöntem olarak önerilmiştir. Bu yöntemde; ölçeğin yarısının orijinal dilde ve diğer yarısının hedef dilde oluşturulması ve her iki dili bilen bir örnekleme uygulanması neticesinde; (a) orijinal ve hedef dildeki ortalamaların istatistiksel olarak ilişkilerinin hesaplanması, (b) orijinal ve hedef dildeki madde yığınlarının birbirleri arasındaki korelasyon değerlerinin hesaplanması, (c) her iki dildeki formlar için iç tutarlılık ve test-tekrar güvenilirliklerinin hesaplanması ve bunlara ilave olarak (d) madde yanlılı̆̆ için MTK ile hesaplamaların yapılması neticesinde elde edilen bulgular 1şı̆̆ında denkliğin olup olmadığına kanaat getirilmektedir (Mallinckrodt \& Wang, 2004).

\section{YÖNETIM VE ÖRGÜT ALANINDA YAPILMIŞ OLAN ÖLÇEK UYARLAMA ÇALIŞMALARININ ICÇERIKK ANALIZI ILLE INCELENMESI}

Çalışmanın bu bölümünde, Türkiye'de yönetim ve örgüt alanında yapılmış olan ölçek uyarlama çalışmaları içerik analizi yöntemiyle incelenerek, uygulanan ölçek uyarlama süreç ve pratiklerinin evrensel yazında temel kabul gören ilke ve prosedürlere ne ölçüde uygun olduğu tespit edilmeye çalışılacaktır.

\section{1. Örneklem ve Dâhil Edilme Kriterleri}

Uyarlama çalışmalarında takip edilmesi gereken yöntemlere yönelik yazındaki bilgi birikiminin zamanla arttığı ve bu bilgi birikiminin önceki dönemlerdeki hatalı/noksan uygulamaları giderici bir etki yaratarak son yıllarda yapılmış olan çalışmalara olumlu yönde yansımış olduğu varsayımından hareketle; ölçek uyarlama çalışmalarındaki güncel eğilimleri ve hâlihazırdaki durumu tespit etmek amacıyla, son yıllarda yapılmış olan çalışmaların bu araştırmaya dâhil edilmesinin daha uygun olacağına kanaat getirilmiştir. Bu kapsamda, araştırma örneklemine; (a) 2010 yılından 
Şekil 1: İçerik analizinde takip edilen basamaklar.

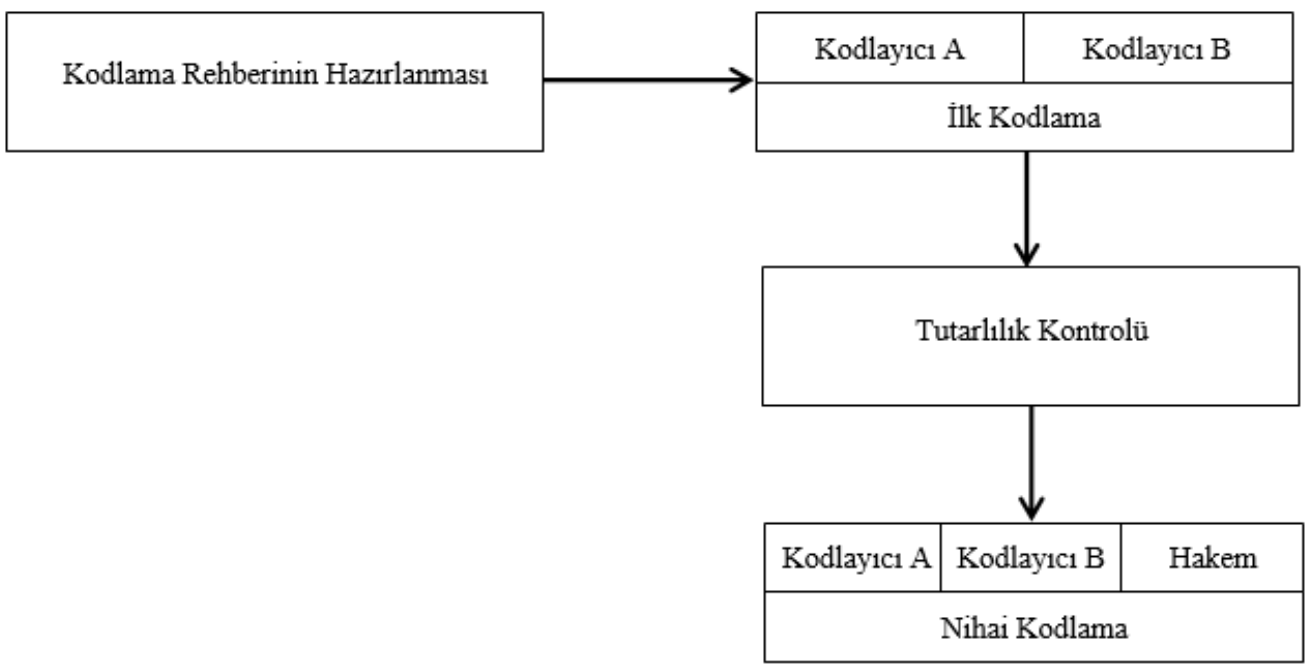

2015 yılı sonuna kadar olan dönemde yayınlanmış, (b) yönetim ve örgüt alanına ait, (c) görgül araştırma makalesi niteliği taşıyan ve (d) farklı bir dildeki bir ya da birden fazla ölçeği Türkçe'ye uyarlama çalışması yapmış olan çalışmalar dâhil edilmiştir. $\mathrm{Bu}$ amaç doğrultusunda; TÜBİTAK ULAKBIM Ulusal Veri Tabanı, Google Scholar, EBSCO, Springer, Taylor ve Francis veri tabanlarında; "uyarlama", "ölçek uyarlama", “Türkçe’ye uyarlama”, "uyarlanma”, “tercüme”, "geri-tercüme”, “çeviri”, "geri-çeviri”, “dilsel eşdeğerlik", "geçerlilik”, "güvenilirlik”, "geçerlilik ve güvenilirlik çalışması", "Türkçe", "Türkçe formu", "Turkish", "adaptation", "validation", "validity" ve "reliability" anahtar kelimeleri kullanılarak elektronik tarama yapılmıştır. Yapılan elektronik tarama neticesinde yukarıdaki kriterleri sağladığı tespit edilen 45 adet ölçek uyarlama çalışması, araştırmanın örneklemini oluşturmaktadır.

\section{2. İçerik Analizi}

$\mathrm{Bu}$ araştırmada, örnekleme dâhil edilen çalışmaların incelenmesinde içerik analizi yöntemi (Tavşancıl \& Aslan, 2001) kullanılmıştır. İçerik analizi Şekil-1'de sunulan basamaklar takip edilerek yapılmıştır.

İlk olarak kodlama rehberi hazırlanmıştır. Ölçek uyarlaması ile ilgili olarak yazında belirtilen hususlar ve ölçek uyarlama çalışmaları konusunda daha önce yapılmış olan araştırmalardan (Çüm \& Koç, 2013; Erdemir, 2008; Güvendir \& Özkan, 2015; Özen, 2000; Öztürk vd., 2015) istifade edilmek suretiyle; aşağıda sunulan 11 adet kodlama kriteri belirlenmiştir.

- Yeni bir ölçek geliştirme ya da uyarlama çalışmasına yönelik bir kararın verilip verilmediği,
- Kaynak dil,

- Geri-çeviri yapılıp yapılmadığı,

- Uzman/hakem görüşü alınıp alınmadığı,

- Çeviri, geri-çeviri ve uzman/hakem görüşüne başvurmada uygulanan yöntemin (tek kişi ya da komisyon) ne olduğu,

- Çeviri yapanların her iki dili bilmesinin yanında diğer gerekli nitelikleri taşıyıp taşımadiğı,

- Ön test uygulanıp uygulanmadığı,

- Ön test katılımcı sayıs1,

- Türkçe'ye uyarlaması yapılan orijinal ölçeğe ait psikometrik değerlerin raporlanıp raporlanmadığ

- Ölçeğin Türkçe'ye uyarlanmış hali için psikometrik ölçümlerin yapılıp yapılmadığı ve psikometrik değerlerin raporlanıp raporlanmadiğ

- $\quad$ Madde analizinin yapılıp yapılmadığı.

$\mathrm{Bu}$ kodlama kriterlerine ait alt özellikler de tespit edilerek (bknz. Tablo-4) kodlama rehberi oluşturulmuştur. İkinci aşamada; örnekleme dâhil edilen 45 adet ölçek uyarlama çalışmasının ilk kodlaması araştırmacılar tarafindan (Kodlayıcı A ve Kodlayıc1 B) münferit olarak yapılmıştır. Üçüncü aşamada; kodlayıcılar arası tutarlılık kontrolü yapılmıştır. Her iki kodlayıcının birbirlerinden bağımsız olarak yaptıkları kodlamalar incelenerek, kodlayıcılar arasında uzlaşılan ve uzlaşılmayan kodlamalar tespit edilmiştir. $\mathrm{Bu}$ aşamada ayrica; Miles ve Huberman'ın (1994) önerdiği formül (Güvenilirlik = Uzlaşılan kodlama Miktarı / [Uzlaşılan kodlama miktarı + Uzlaşılmayan kodlama Miktarı]) kullanılarak kodlayıcılar arası uyuşma yüzdesinin belirlenmesi suretiyle (Gürbüz \& Şahin, 2015), ilk kodlama faaliyetinin güvenilirliği \% 91 olarak hesaplanmıştır. 
Tablo 4: Ölçeklerin Türkçe'ye Uyarlanmasında Halihazırda Takip Edilen Yöntemlerin Tespitine Yönelik Bulgular

\begin{tabular}{|c|c|c|c|c|c|c|c|}
\hline $\begin{array}{l}\text { S. } \\
\text { Nu }\end{array}$ & \multicolumn{2}{|c|}{ Kriterler } & \multicolumn{2}{|c|}{ Alt Özellikler } & Frekans & $\%$ & Açıklamalar \\
\hline \multirow{2}{*}{1} & \multirow{2}{*}{\multicolumn{2}{|c|}{$\begin{array}{c}\text { Ōlçek geliştirme/uyarlama } \\
\text { kararı verilmesi }\end{array}$}} & \multicolumn{2}{|l|}{ Belirtilmiş } & 3 & 6,7 & \\
\hline & & & \multicolumn{2}{|l|}{ Belirtilmemiş } & 42 & 93,3 & \\
\hline \multirow{2}{*}{2} & \multirow{2}{*}{\multicolumn{2}{|c|}{ Kaynak Dil }} & \multicolumn{2}{|l|}{ İngilizce } & 45 & 100 & \\
\hline & & & \multicolumn{2}{|l|}{ Diğger } & - & 0 & \\
\hline \multirow[b]{2}{*}{3} & \multirow{2}{*}{\multicolumn{2}{|c|}{$\begin{array}{l}\text { Geri-Çeviri Yapılıp } \\
\text { Yapılmadığ }\end{array}$}} & \multicolumn{2}{|l|}{ Yapılmış } & 33 & 73,3 & \\
\hline & & & \multicolumn{2}{|c|}{ Belirtilmemiş/Yapılmamış } & 12 & 26,7 & $\begin{array}{l}\text { Bir çalışmada kasıtlı } \\
\text { olarak geri-çeviri } \\
\text { yapılmamıştır. }\end{array}$ \\
\hline \multirow[t]{2}{*}{4} & \multirow{2}{*}{\multicolumn{2}{|c|}{$\begin{array}{l}\text { Uzman/hakem görüşü alınıp } \\
\text { alınmadığı }\end{array}$}} & \multirow{2}{*}{\multicolumn{2}{|c|}{ Belirtilmemig//Alnmamış }} & 38 & 84,4 & $\begin{array}{l}11 \text { çalışmada geri- } \\
\text { tercüme yapılmadan } \\
\text { görüş alınmıştır. }\end{array}$ \\
\hline & & & & & 7 & 15,6 & \\
\hline \multirow{9}{*}{5} & \multirow{9}{*}{$\begin{array}{c}\text { Tek } \\
\text { Kişi/Komisyon } \\
\text { Yöntemi }\end{array}$} & \multirow{3}{*}{ Çeviri } & \multicolumn{2}{|l|}{ Tek Kişi } & 9 & 20 & \\
\hline & & & \multicolumn{2}{|l|}{ Komisyon } & 33 & 73,3 & \\
\hline & & & \multicolumn{2}{|l|}{ Yöntem Belirtilmemiş } & 3 & 6,7 & \\
\hline & & & \multicolumn{2}{|l|}{ Tek Kişi } & 11 & 24,4 & \\
\hline & & Geri-Çeviri & \multicolumn{2}{|l|}{ Komisyon } & 17 & 37,8 & \\
\hline & & & \multicolumn{2}{|l|}{ Yontem Belirtilmemiş } & 5 & 11,1 & \\
\hline & & & \multicolumn{2}{|l|}{ Tek Kişi } & 5 & 11,1 & \\
\hline & & $\begin{array}{c}\text { Uzman/Hakem } \\
\text { Göpiëi }\end{array}$ & \multicolumn{2}{|l|}{ Komisyon } & 31 & 68,9 & \\
\hline & & & Yöntem Belirtilmemiş & & 2 & 4,4 & \\
\hline & & & & $\begin{array}{l}\text { Her iki kültürü } \\
\text { iyi bilme }\end{array}$ & 8 & 17,8 & \\
\hline & & & Çeviri yapanlarda & $\begin{array}{l}\text { Olçūlecek yapı } \\
\text { hakkında bilgi } \\
\text { sahibi olma }\end{array}$ & 7 & 15,6 & \\
\hline & & & & $\begin{array}{l}\text { Temel } \\
\text { psikometri } \\
\text { bilimine vakif } \\
\text { olma }\end{array}$ & 3 & 6,7 & \\
\hline & & & & $\begin{array}{l}\text { Her iki kültürü } \\
\text { iyi bilme }\end{array}$ & 4 & 8,9 & \\
\hline & $\begin{array}{l}\text { Çeviri ve geri- } \varsigma \\
\text { ile uzman/hake }\end{array}$ & mlerin her iki & Geri-çeviri yapanlarda & $\begin{array}{l}\text { Ölçülecek yapı } \\
\text { hakkłanda bilgi } \\
\text { sahibi olma }\end{array}$ & - & 0 & \\
\hline 0 & $\begin{array}{r}\text { dili bilmesinin } \\
\text { gerekli niteli } \\
\text { tą̧ım }\end{array}$ & $\begin{array}{l}\text { yanında diger } \\
\text { kleri taşıyıp } \\
\text { adığı }\end{array}$ & & $\begin{array}{l}\text { Temel } \\
\text { psikometri } \\
\text { bilimine vakif } \\
\text { olma }\end{array}$ & - & 0 & \\
\hline & & & & $\begin{array}{l}\text { Her iki kültürü } \\
\text { iyi bilme }\end{array}$ & 2 & 4,4 & \\
\hline & & & Uzman/hakem & $\begin{array}{l}\text { Olçülecek yapı } \\
\text { hakkında bilgi } \\
\text { sahibi olma }\end{array}$ & 9 & 20 & \\
\hline & & & & $\begin{array}{l}\text { Temel } \\
\text { psikometri } \\
\text { bilimine vakif } \\
\text { olma }\end{array}$ & 3 & 6,7 & \\
\hline & & & Belirtilmemiģ & & 26 & 57,8 & \\
\hline & & & $\begin{array}{l}\text { Her iki dili bilen bir örn } \\
\text { dildeki ölçeğin ve Türk } \\
\text { ölçeğin uygulanması }\end{array}$ & $\begin{array}{l}\text { leme orijinal } \\
\text { 'ye uyarlanmıs }\end{array}$ & 13 & 28,9 & \\
\hline & & & Anket (Anlamlilik, Aç1) & k, vb.) & 9 & 20 & \\
\hline 7 & On 1 & rest & Odak Grup Çalışması & & 1 & 2,2 & \\
\hline & & & DFA & & 2 & 4,4 & \\
\hline & & & Yapılmış ancak teknik & lirtilmemiş & 2 & 4,4 & \\
\hline & & & Belirtilmemiş/Yapılmar & & 18 & 40 & \\
\hline
\end{tabular}


Tablo 4: Ölçeklerin Türkçe'ye Uyarlanmasında Hâlihazırda Takip Edilen Yöntemlerin Tespitine Yönelik Bulgular (Devam)

\begin{tabular}{|c|c|c|c|c|c|c|}
\hline \multirow{5}{*}{8} & \multirow{5}{*}{\multicolumn{2}{|c|}{ Ön Test Katılımc1 Sayıs1 }} & 5 den az & - & 0 & \\
\hline & & & $5-10$ & 6 & 13,3 & \\
\hline & & & $10-20$ & 2 & 4,4 & \\
\hline & & & 20 'den fazla & 16 & 35,6 & \\
\hline & & & Belirtilmemiş & 3 & 6,7 & \\
\hline \multirow{18}{*}{9} & \multirow{18}{*}{$\begin{array}{c}\text { Orijinal } \\
\text { Dildeki Ölçeğe } \\
\text { Ait } \\
\text { Psikometrik } \\
\text { Değerlerin } \\
\text { Raporlanmas1 }\end{array}$} & \multicolumn{2}{|l|}{ Sadece AFA } & 7 & 15,6 & $\begin{array}{l}\text { Dördünde sayısal } \\
\text { değer verilmemiştir. }\end{array}$ \\
\hline & & \multicolumn{2}{|l|}{ Sadece DFA } & 3 & 6,7 & \\
\hline & & \multicolumn{2}{|c|}{ AFA ve DFA birlikte } & 5 & 11,1 & $\begin{array}{l}\text { İkisinde sayısal } \\
\text { değer verilmemiştir. }\end{array}$ \\
\hline & & \multicolumn{2}{|c|}{ Belirtilmemiş/Yapılmamış } & 30 & 66,7 & $\begin{array}{l}\text { Birisinde orijinal } \\
\text { kaynakta } \\
\text { belirtilmemiştir. }\end{array}$ \\
\hline & & \multirow{8}{*}{ Geçerlilik } & Görünüş Geçerliliği & - & 0 & \\
\hline & & & İçerik Geçerliliği & - & 0 & \\
\hline & & & Ölçüte Dayalı Geçerlilik & 6 & 13,3 & $\begin{array}{l}\text { İkisinde sayısal } \\
\text { değer verilmemiştir. }\end{array}$ \\
\hline & & & Yap1 Geçerliliği & 13 & 28,9 & $\begin{array}{l}\text { Altısında sayısal } \\
\text { değer verilmemiştir. }\end{array}$ \\
\hline & & & İç Geçerlilik & - & 0 & \\
\hline & & & D1ş Geçerlilik & - & 0 & \\
\hline & & & Genel Olarak Geçerli Olduğu Belirtilmiş & 1 & 2,2 & $\begin{array}{l}\text { Sayısal değer } \\
\text { verilmemiştir. }\end{array}$ \\
\hline & & & Belirtilmemiş & 30 & 66,7 & $\begin{array}{l}\text { Birisinde orijinal } \\
\text { kaynakta } \\
\text { belirtilmemiştir. }\end{array}$ \\
\hline & & \multirow{6}{*}{ Güvenilirlik } & Cronbach Alpha & 27 & 60 & \\
\hline & & & Test-Tekrar & 5 & 11,1 & \\
\hline & & & Yaryya Bölme & 1 & 2,2 & \\
\hline & & & Madde-toplam Puan Korelasyonu & 4 & 8,9 & \\
\hline & & & $\begin{array}{l}\text { Genel Olarak Güvenilir Olduğu } \\
\text { Belirtilmiş }\end{array}$ & 1 & 2,2 & $\begin{array}{l}\text { Sayısal değer } \\
\text { verilmemiştir. }\end{array}$ \\
\hline & & & Belirtilmemiş & 17 & 37,8 & \\
\hline \multirow{19}{*}{10} & \multirow{19}{*}{$\begin{array}{l}\text { Ölçeklerin } \\
\text { Türkçe'ye } \\
\text { Uyarlanmış } \\
\text { Hali için } \\
\text { Psikometrik } \\
\text { Değerlerin } \\
\text { Ōlçülmesi ve } \\
\text { Raporlanması }\end{array}$} & Sadece AFA & & 8 & 17,8 & \\
\hline & & Sadece DFA & & 16 & 35,6 & $\begin{array}{l}\text { Birisinde En Küçük } \\
\text { Uzay Analizi } \\
\text { (EKUA) yapılmıștır. }\end{array}$ \\
\hline & & AFA ve DFA & irlikte & 20 & 44,4 & \\
\hline & & Belirtilmemiş/ & Tapilmamış & 1 & 2,2 & \\
\hline & & \multirow{7}{*}{ Geçerlilik } & Görünüş Geçerliliği & - & 0 & \\
\hline & & & İçerik Geçerliliği & 4 & 8,9 & \\
\hline & & & Ölçüte Dayalı Geçerlilik & 11 & 24,4 & \\
\hline & & & Yap1 Geçerliliği & 44 & 97,8 & $\begin{array}{l}\text { İlave olarak; } \\
\text { çalışmaların } 6 \text { adedi } \\
\text { ayrışım geçerliliği, } 2 \\
\text { adedi benzeşim } \\
\text { geçerliliği yaptığını } \\
\text { raporlamıştır. }\end{array}$ \\
\hline & & & İç Geçerlilik & - & 0 & \\
\hline & & & 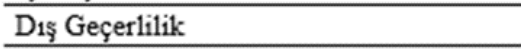 & - & 0 & \\
\hline & & & Belirtilmemiş/Yapılmamış & - & 0 & \\
\hline & & \multirow{8}{*}{ Güvenilirlik } & Cronbach Alpha & 44 & 97,8 & \\
\hline & & & Test-Tekrar & 18 & 40 & \\
\hline & & & Yaryya Bölme & 7 & 15,6 & \\
\hline & & & Madde-toplam Puan Korelasyonu & 27 & 60 & \\
\hline & & & Sadece bir teknik & 13 & 28,9 & $\begin{array}{l}12 \text { Cronbach Alpha, } \\
1 \text { test-tekrar. }\end{array}$ \\
\hline & & & Aynı anda iki teknik & 16 & 35,6 & \\
\hline & & & İkiden fazla teknik & 16 & 35,6 & \\
\hline & & & Belirtilmemiş/Yapılmamış & - & 0 & \\
\hline \multirow{3}{*}{11} & \multirow{3}{*}{ Madde Analizi } & \multicolumn{2}{|c|}{ \%27 Alt Grup-\%27 Üst Grup Karş1laştır1ması } & 12 & 26,7 & \\
\hline & & \multicolumn{2}{|c|}{ Madde-Toplam Puan Korelasyonu } & 27 & 60 & \\
\hline & & \multicolumn{2}{|c|}{ Belirtilmemiş/Yapılmamış } & 15 & 33,3 & \\
\hline
\end{tabular}


Son aşama olan dördüncü aşamada; nihai kodlama yapılmıştır. Tutarlılık kontrolü neticesinde tespit edilmiş olan uzlaşılmayan kodlamalar üzerindeki ihtilafı ortadan kaldırmak amacıyla, ölçek uyarlama olan hususları incelemesine başvurulmuştur. İtilaflı kodlamalar; Kodlayıcı A, Kodlayıcı B ve Hakem'den oluşan üç kişilik komisyonun oylamasına sunularak nihai karara bağlanmıştır.

\subsection{Bulgular}

İçerik analizi neticesinde elde edilen bulgular Tablo-4'te sunulmuştur. İçerik analizi yapılan 45 çalışma ile ilgili olarak elde edilen bulgular incelendiğinde, ölçek uyarlama çalışmalarının \%93,3'ünde (42 çalışma); hedef yapının Türkiye bağlamında ölçülmesi amacıyla, yeni bir ölçek geliştirilmesi ya da farklı bir dilde mevcut olan bir ölçeğin Türkçe'ye uyarlanması hususunda karar verilmesine yönelik bir değerlendirme yapılmadı̆̆ belirlenmiştir. Çalışmaların sadece \%6,7'sinde (3 çalışma) bu hususun değerlendirmeye alınarak, yeni bir ölçek geliştirmek yerine mevcut olan bir ölçeğin Türkçe'ye uyarlanmasının daha uygun olacağı kararına ulaşıldığı tespit edilmiştir.

İncelenen çalışmalarda; uyarlanan ölçeklerin kaynak dilinin tamamının İngilizce olduğu tespit edilmiştir. Çalışmaların \%26,7'sinde (12 çalışma) geri-çeviri yapılmadığı veya yapılıp yapılmadığının belirtilmediği belirlenmiştir. Ayrıca bir çalışmada geri-çevirinin kasıtlı olarak yapılmadığı (geri-çeviri yönteminde; karşılaştırmaların kaynak dilde yapıldığı ve hedef dildeki aksaklıkların yeterince belirlenemediği hususları gerekçe gösterilerek) ifade edilmiştir. Çalışmaların \%84,4'ünde (38 çalışma) uzman görüşü alınmış olmakla birlikte, uzman görüşüne başvurulmuş olan bu 38 çalışmanın \%28,9'unda (11 çalışma) geri-çeviri yapılmamış olduğu tespit edilmiştir. Bir çalışmada ise ölçekteki soruların sadece yarısının geriçevirisinin yapıldı $\breve{g}_{1}$ (gerekçe belirtilmeksizin) bildirilmiştir.

Çeviri, geri-çeviri ve uzman/hakem görüşüne başvurmada tek kişi ya da komisyon yönteminin kullanılmasında büyük farklılıklar bulunduğu tespit edilmiştir. Çeviriler için; çalışmaların \%20'sinde (9 çalışma) tek kişi yönteminin, \%73,3'ünde (33 çalışma) komisyon yönteminin kullanıldığ 1 ve çalışmaların \%6,7'sinde (3 çalışma) hangi yöntemin kullanıldığının rapor edilmediği belirlenmiştir. Geri-çeviriler için; çalışmaların \%24,4'ünde (11 çalışma) tek kişi yönteminin, \%37,8'inde (17 çalışma) komisyon yönteminin kullanıldığı ve çalışmaların \%11,1'inde (5 çalışma) hangi yöntemin kullanıldığının rapor edilmediği tespit edilmiştir. Uzman/hakem grupları için; çalışmaların \%11,1'inde (5 çalışma) tek kişi yönteminin, \%68,9'unda (31 çalıșma) komisyon yönteminin kullanıldığı ve çalışmaların \%4,4'ünde ( 2 çalışma) hangi yöntemin kullanıldığının rapor edilmediği bulgusuna ulaşılmıştır. Ölçek uyarlama çalışmalarında komisyon yönteminin kullanımının yeterli düzeyde olmasa da yaygın olduğu; çeviri ve uzman/hakem gruplarına kıyasla geri-çevirilerde komisyon yönteminin çok daha az düzeyde kullanıldığı göze çarpmaktadır. İncelenen çalışmaların birisinde ise geri-çevirinin, çeviriyi yapan aynı kişiler tarafindan yapıldığı bildirilmiştir.

Çeviri ve geri-çeviri yapanlar ile uzman/hakem grubunun, her iki dili bilmesinin yanında her iki kültürü de iyi bilmesi ve ölçülecek yapı ile psikometri hakkında da bilgi sahibi olması gerekiyor olmasına rağmen (Ægisdóttir vd., 2008; Hambleton, 1993; Hambleton \& Patsula, 1999; Van de Vijver \& Hambleton, 1996) bu hususa da çalışmalarda yeterince önem verilmediği görülmektedir. Çeviri yapanların; her iki kültürü de iyi bilme niteliği çalışmaların \%17,8'inde (8 çalışma), ölçülecek yapı hakkında bilgi sahibi olma niteliği çalışmaların \%15,6'sında (7 çalışma) ve temel psikometri bilimine vakıf olma niteliği ise çalışmaların sadece \%6,7'sinde (3 çalışma) dikkate alınarak bu özelliklere sahip olan kişilerin seçildiği ortaya çıkmıştır. Geri-çeviri yapanların; her iki kültürü de iyi bilme niteliği çalışmaların sadece \%8,9'unda (4 çalışma) dikkate alınmış; ölçülecek yapı hakkında bilgi sahibi olma ve temel psikometri bilimine vakıf olma niteliklerinin ise çalışmaların hiçbirinde dikkate alınmadığı bulgusuna ulaşılmıştır. Uzman/hakem grubunun; her iki kültürü de iyi bilme niteliği çalışmaların \%4,4'ünde (2 çalışma), ölçülecek yapı hakkında bilgi sahibi olma niteliği çalışmaların \%20'sinde (9 çalışma) ve temel psikometri bilimine vakıf olma niteliği ise çalışmaların \%6,7'sinde (3 çalışma) dikkate alınarak bu özelliklere sahip olan kişilerin seçildiği belirlenmiştir. Bahse konu üç niteliğe sahip olunması durumunun; çeviri, geri-çeviri ve uzman/hakem görüşü belirtme gibi farklı görevler için çalışmaların her birinde farklılaştığı; çalışmaların hiçbirinde çeviri, geri-çeviri ve uzman görüşü gruplarının tamamının bahse konu üç niteliğin hepsini birden taşıyan kişilerden oluşturulmuş olmadığı ortaya çıkmıştır. Ayrıca; yine bu üç niteliğin gereklerinin her üçüne birden bakmamış olan çalışmaların oranının ise \%57,8 (26 çalışma) olduğu tespit edilmiştir

Çalışmalarda ön test yapma tercihinin \%60 (27 çalışma) oranında olduğu ve geri kalan çalışmaların (\%40 - 18 çalışma) ön test uygulamadığ 1 ya da bu konu hakkında bilgi rapor etmediği tespit edilmiştir. Ön testlerde; \%28,9 oranla (13 çalışma); her iki dili bilen bir örnekleme, orijinal dildeki ölçeğin ve Türkçe'ye uyarlanmış ölçeğin her ikisinin bir süre 
ara ile uygulanması yönteminin en fazla tercih edildiği görülmektedir. Çalışmaların \%20'sinde (9 çalışma) ise ölçeğin anlamlılığının, açıklığının vb. katılımcılar tarafindan değerlendirildiği anket tekniğinin ön test kapsamında uygulandığ 1 belirlenmiştir. Ayrıca, ön test yapılmış olan çalışmaların, ön test katılımcı sayıları bakımından birbirlerinden farklılaştıkları tespit edilmiştir.

Uyarlama çalışması yapılan ölçeklerin orijinal halleri için sunulan geçerlilik ve güvenilirlik ile ilgili hususlar incelendiğinde; çalışmaların \%66,7'sinde (30 çalışma) orijinal ölçek için geçerlilik ile ilgili bilgilerden bahsedilmediği tespit edilmiştir. Orijinal ölçeklerin geçerlilikleri ile ilgili verilen bilgilerde; daha çok yapı geçerliliği (\%28,9 - 13 çalışma) ve ölçüte dayalı geçerlilikten $(\% 13,3$ - 6 çalışma) bahsedildiği bulgusuna ulaşılmıştır. Çalışmaların \%11,1'inde (5 çalışma) AFA ve DFA değerlerine birlikte yer verildiği, \%66,7'sinde ise (30 çalışma) orijinal ölçek ile ilgili AFA veya DFA bulgularına hiçbir şekilde yer verilmediği tespit edilmiştir. Güvenilirlik ile ilgili olarak ise çalışmaların çoğunlukla ( $\% 60 \quad-27$ çalışma) Cronbach Alpha değerlerini rapor ettikleri, ancak \%37,8 (17 çalışma) gibi büyük bir kısmının ise orijinal dildeki ölçeğin güvenilirlik değerlerini rapor etmedikleri tespit edilmiştir.

Ölçeklerin Türkçe'ye uyarlanmış hali için sunulan geçerlilik ve güvenilirlik ile ilgili hususlar incelendiğinde, AFA ve DFA uygulamaları ile ilgili olarak; \%17,8'inin (8 çalışma) sadece AFA bulgularını, \%35,6'sının (16 çalışma) ise sadece DFA bulgularını rapor ettikleri; \%44,4'ünün (20 çalışma) AFA ve DFA bulgularına birlikte yer verdikleri tespit edilmiştir. Çalışmaların \%2,2'sinde (1 çalışma) ise AFA veya DFA bulgularına hiçbir şekilde yer verilmediği görülmüştür. Diğer yandan, çalışmaların sadece birisinde; yapı geçerliliğinin test etmek amaciyla öncelikle DFA uygulandığ 1 ve DFA'dan elde edilen bulguların uygun olmadığının tespit edilmesinin ardından AFA uygulandığ belirtilmiştir. Yapı geçerliliği kapsamında; çalışmaların \%13,3'ünde (6 çalışma) ayrışım geçerliliği ve \% 4,5'inde (2 çalışma) benzeşim geçerliliğine bakıldığı tespit edilmiştir. Yine çalışmaların \%24,4'ünde (11 çalışma) ölçüte dayalı geçerliliğe ve \%8,9'unda (4 çalışma) ise içerik geçerliliğine bakıldığı tespit edilmiştir.

Uyarlanan ölçeklerin güvenilirlik değerlerinin hesaplanması ve rapor edilmesi ile ilgili olarak; çalışmaların \%97,8'inde (44 çalışma) Cronbach Alpha değerlerinin raporlandığı; \%60'ında (27 çalışma) madde-toplam puan korelasyon değerlerine yer verildiği ve \%40'ında (18 çalışma) test-tekrar yönteminin uygulandığı bulgusuna ulaşılmıştır. Çalışmaların \%35,6'sında (16 çalışma) ikiden fazla çeşit güvenilirlik hesaplama tekniğinin kullanıldığı, diğer \%35,6'sında (16 çalışma) aynı anda iki farklı çeşit güvenilirlik hesaplama tekniğinin kullanıldığ 1 , geri kalan \%28,9'unda (13 çalışma) ise sadece bir çeşit güvenilirlik hesaplama tekniğinin kullanıldığı ve güvenilirlik değerlerine yer vermeyen herhangi bir çalışmanın mevcut olmadığı tespit edilmiştir.

Madde analizi kapsamında çalışmaların \%26,7'sinin (12 çalışma) \%27 alt grup -\%27 üst grup karşılaştırma tekniğini, \%60’ının (27 çalışma) madde-toplam puan korelasyonu tekniğini kullandığı; \%33,3'ünün (15 çalışma) madde analizini yapmadığı ya da yaptığına dair bilgi vermediği tespit edilmiştir.

\section{TARTIŞMA, ÖNERİLER VE SONUÇ}

Bu çalışmada; yanlılık, denklik ve ölçek uyarlama çalışmalarında uygulanması gerekli olan hususlara açıklık getirilmesi, yönetim ve örgüt alanında, yabancı dilde geliştirilmiş ölçeklerin Türkçe'ye uyarlanması çalışmalarında hâlihazırda nasıl bir uygulama izlendiğinin tespit edilmesi ve yabanc1 dilden Türkçe'ye ölçek uyarlama konusunda bundan sonra yapılacak çalışmalarda takip edilmesi gereken temel adımlara ilişkin öneriler getirilmesi amaçlanmıştır.

Bu kapsamda, 2010-2015 yılları arasında, Türkiye'de yönetim ve örgüt alanında yapılmış 45 adet ölçek uyarlama çalışması içerik analizi tekniği ile incelenmiştir. İçerik analizi bulguları incelendiğinde; ölçek uyarlama çalışmalarında takip edilen uygulamaların birbirlerinden farklı olduğu; uygulamada üzerinde en çok fikir birliği olan hususların ise ölçeklerin Türkçe'ye uyarlanmış halleri için yapı geçerliliğine dair analizler yapılması $(\% 97,8 \quad-\quad 44 \quad$ çalışma $)$ ve güvenilirliklerinin Cronbach Alpha katsayısı ile hesaplanması (\%97,8 - 44 çalışma) olduğu ortaya çıkmıştır.

Özen (2000), yönetim/organizasyon yazınında kongre bildirileri (1996-1998 yılları aras1) üzerinden yöntem sorununa yöneldiği araştırmasında, araştırmaların \%76,9'unda kullanılan ölçeklerin geçerlilik ve güvenilirlik düzeylerinin hesaplanmadığını/belirtilmediğini tespit etmiştir. Yine yönetim ve örgüt alanındaki kongre bildirilerini (2002-2007 y1lları aras1) inceleyen Erdemir (2008); bildirilerin \%87'sinde geçerlilik ile ilgili bulguların ve \%42'sinde ise güvenilirlik ile ilgili bulguların belirtilmediği sonucuna ulaşmıştır. Bu çalışmada ise geçerlilik ve güvenilirlik düzeyleri ile ilgili olarak; yap1 
geçerliliği ve iç tutarlılık güvenilirliğinin (Cronbach Alpha) çalışmaların sadece birisi hariç diğerlerinde hesaplanarak rapor edildiği (97,8 - 44 çalışma) tespit edilmiştir. Ayrıca Erdemir (2008); incelediği çalışmaların \%13'ünde sadece DFA uygulandığını, \%25'inde sadece AFA uygulandığını ve yine \%25'inde hem AFA ve hem DFA uygulandığını rapor etmiştir. Bu araştırmada ise; örnekleme dâhil edilen çalışmaların \%35,6'sında sadece DFA, $\% 17,8$ 'inde sadece AFA ve \%44'ünde ise hem DFA ve hem de AFA uygulanmış olduğu tespit edilmiştir.

Bu çalışmanın bulguları, geçmiş yıllarda yönetim ve örgüt alanında (Erdemir, 2008; Özen, 2000) ve diğer alanlarda (Çüm \& Koç, 2013; Güvendir \& Özkan, 2015; Öztürk vd., 2015) yapılmış benzer çalışmaların bulguları ile karşılaştırıldığında, yönetim ve örgüt alanında yapılan ölçek uyarlama çalışmalarında olumlu yönde ilerlemelerin gerçekleşmekte olduğu görülmektedir. Başka bir anlatımla, uyarlama çalışmalarında takip edilmesi gereken yöntemlere yönelik bilgi birikiminin zamanla arttığ 1 ve bu bilgi birikiminin son yıllarda yapılmış olan çalışmalara olumlu yönde yansıdığı ifade edilebilir. $\mathrm{Bu}$ iyimser gelişmelere rağmen; ölçek uyarlama çalışmalarında, yazında genel kabul gören ilke ve aşamaların yeterli ölçüde takip edilmediği ve uygulanan yöntemlerin büyük ölçüde birbirlerinden farklılaştıkları tespit edilmiştir. $\mathrm{Bu}$ nedenle, hatalı uygulamaları en aşağı seviyelere çekebilmek ve ölçek uyarlama çalışmalarında metodoloji birliği sağlamak amacıyla uyarlama süreçlerinde takip edilmek üzere bazı önerilerde bulunulmasının uygun olacağı değerlendirilmiştir. Geçerli ve kabul edilebilir bir ölçek uyarlama çalışması için temel aşamalara ihtiyaç bulunmaktadır. Bu ihtiyaca yönelik olarak; bu araştırmanın yazarlarının kişisel tecrübeleri, ölçek uyarlama ile ilgili yazında belirtilen hususlar (örneğin, Brislin, 1970, 1976, 1986; Brislin vd., 1973; Ægisdóttir vd., 2008) ve ITC ilkeleri göz önünde bulundurularak oluşturulan ve Şekil-2'de önerilen temel aşamaların ölçek uyarlama çalışmalarında takip edilmesi esas alınabilir.

İlk olarak ölçek uyarlama ya da ölçek geliştirme çalışmalarından hangisinin yapılacağı yönünde gerekçelendirilmiş bir karar verilmelidir (Ægisdóttir vd., 2008; Hambleton \& Patsula, 1999). Ölçek uyarlama çalışmasına başlamadan önce; Türkiye kültürüne ait yeni bir ölçeğin mi geliştirileceği ya da diğer bir kültürde geliştirilmiş olan bir ölçeğin mi Türkçe'ye uyarlanmak suretiyle kullanılacağı belirlenmelidir. Bu hususa ilave olarak; ölçülmek istenen yapı ile ilgili ve psikometrik özellikleri yeterli olan bir Türkçe ölçek mevcut ise yeni bir uyarlama çalışması içine girilmemelidir. $\mathrm{Bu}$ nedenlerle, neden bir ölçek uyarlama çalışması yapılmasına karar verildiği gerekçelendirilmelidir.

İkinci aşamada çeviri yapılmalıdır. Her iki dili ve kültürü bilen, ölçülecek yapıya ve psikometriye hâkim en az iki kişilik bir komisyon ile ölçeğin orijinal dilinden Türkçe'ye çevirisi yapılmalıdır. Çeviri; önce grup üyeleri tarafindan birbirlerinden bağımsız olarak yapılmalı, daha sonra grup üyelerinin çevirilerinin karşılaştırılması yapılmalı ve en uygun çeviriye varıldığına kanaat getirilinceye kadar çalışmaya devam edilmelidir (Ægisdóttir vd., 2008).

Üçüncü aşamada geri-çeviri yapılmalıdır (Brislin, 1970, 1976, 1986). Her iki dili ve kültürü bilen, ölçülecek yapıya ve psikometriye hâkim ve çeviriyi yapan kişilerden farklı kişiler olacak şekilde en az

Șekil-2: Kabul edilebilir bir ölçek uyarlama çalıșması ic̣in temel adımlar.

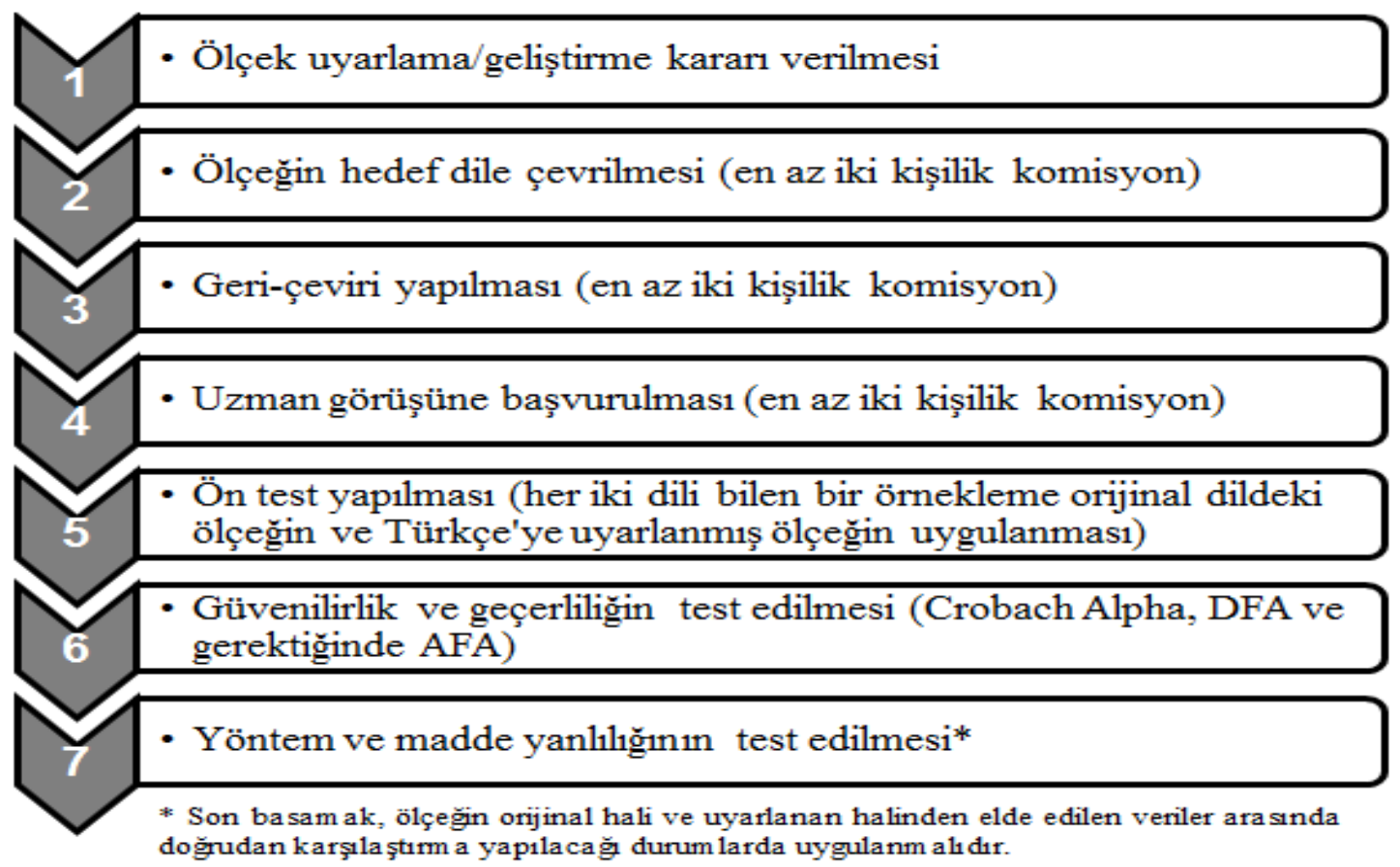


iki kişilik bir komisyon ile ölçeğin Türkçe'den orijinal diline geri-çevirisi yapılmalıdır. Geri-çeviri; önce grup üyeleri tarafından birbirlerinden bağımsız olarak yapılmalı, daha sonra grup üyelerinin çevirilerin karşılaştırılması yapılmalı ve en uygun çeviriye varıldığına kanaat getirilinceye kadar çalışmaya devam edilmelidir (Ægisdóttir vd., 2008).

Dördüncü aşamada uzman görüşüne başvurulmalıdır (Hambleton, 2005; Mallinckrodt \& Wang, 2004). Her iki dili ve kültürü bilen, ölçülecek yapıya ve psikometriye hâkim olan ve aynı zamanda çeviri ile geri-çeviri komisyonlarında görev almamış olan en az iki uzmandan oluşan bir komisyondan; ölçeğin orijinal hali, çevirisi ve geriçevirisini karşılaştırmaları istenerek, ölçeğin çevrilmiş hali en uygun ifadeleri içerecek bir yapıya kavuşturulmalı ve çeviride gerekli düzeltmeler yapılmalidir.

Beşinci aşamada ön test yapılmalıdır (Brislin, 1986; Hambleton \& Patsula, 1999). Ön test yapilarak ölçeğin kendisinden beklenen işlevi yerine getirip getirmediği test edilmelidir. $\mathrm{Bu}$ amaçla; her iki dili bilen bir örneklem grubuna ölçeğin orijinal dildeki halinin ve Türkçe'ye uyarlanmış halinin uygulanması, geri bildirim alınması (uygunluk, açıklık veya anlamlılık vb. anketleri yoluyla) veya odak grup çalışması tekniklerinden herhangi biri uygulanabilir.

Altıncı aşamada uyarlanmış ölçeğin güvenilirliği ve geçerliliği test edilmelidir (Hambleton \& Patsula, 1999; Van de Vijver \& Hambleton, 1996). Güvenilirliği test etmek amacıyla; Cronbach Alpha değeri hesaplanmalıdır. Buna ilave olarak testtekrar güvenilirliği de hesaplanabilir. Uyarlanan ölçeğin geçerliliğini tespit etmek amacıyla ise önce DFA uygulanmalıdır. Eğer DFA neticesinde ölçeğin yapısal ve faktöriyel geçerliliği doğrulanamadı ise (kabul edilebilir modifikasyonlar neticesinde) ölçek maddelerinin ve faktörlerinin arasındaki ilişki örüntüsünü keşfetmek amacıyla ikinci aşamada AFA uygulanmalıdır (Çokluk, Şekercioğlu \& Büyüköztürk, 2012; Gürbüz \& Şahin, 2015). Yapılan AFA sonucunda ölçeğe madde eklemesi veya ölçekten madde çıkarılması gerçekleşti ise tekrar DFA uygulanarak ölçeğin oluşan yeni halinin faktör yapısı doğrulanmalıdır. Ayrıca, ölçeğe madde ekleme ve çıkarma işılemi yapıldığından dolayı ölçeğin yeni faktör yapısının farklı bir örneklemde test edilmesinin uygun olacağ değerlendirilmektedir. Bunlara ilave olarak; uyarlanan ölçeğin benzeşim, ayrışım ve yordama geçerliliklerine yönelik olarak yapılacak analizler ölçeğin yapı geçerliliğini kuvvetlendirecektir.

Son aşamada ise; eğer uyarlanacak olan ölçekten elde edilecek veriler ile orijinal ölçekten elde edilecek veriler doğrudan karşılaştırılacak ise (örneğin t-testi); yap1 yanlılığı, yöntem yanlılığı ve madde yanlılığ1 test edilmelidir (Hambleton, 1996; International Test Commission, 2005; Van de Vijver \& Hambleton, 1996). Yap1 yanlılığının analizinde; AFA ve DFA kullanılabilir. Yöntem yanlılığının mevcut olup olmadığını tespit edebilmek amaciyla; madde-genel ölçek korelasyonları veya incelenen yapının özelliğine göre kontrol değişkenleri olarak sosyal beğenilirlik), tecrübeler, Kişi Başına GSMH ve sosyo-ekonomik statü değerleri ölçülmeli ve kontrol altına alınmalıdır (Ægisdóttir vd., 2008; Johnson, 1998). Madde yanlılığının mevcut olup olmadığı ise; Madde Yanıt Kuramı veya varyans analizi (ANOVA) ile test edilmelidir (Ægisdóttir vd., 2008; Hambleton \& Swaminathan, 1985). Yöntem yanlılığı ve madde yanlılığı ile ilgili olarak önemli olan diğer bir husus; ABD'de geliştirilmiş bir ölçeğin Türkçe'ye ve örneğin Çince'ye uyarlaması daha önceden bir araştırmacı tarafından yapılmışsa ve diğer bir araştırmacı da bu üç ülke (ABD, Türkiye ve Çin) arasında bu ölçekleri kullanarak doğrudan karşılaştırmalar ve analizler yapacak ise (örneğin t-testi) bu ölçeklerin yöntem yanlılığı ve madde yanlılığ da test edilmeli ve yanlılık mevcut ise giderici tedbirler alınmalıdır.

$\mathrm{Bu}$ araştırmanın iki sınırlılı̆̆ olarak; araştırmanın örneklemine 2010 yılından 2015 yılının sonuna kadar yayınlanmış olan ölçek uyarlama çalışmaları dâhil edilmiştir. Bu nedenle, araştırmanın bulgularının daha önceki yıllara genellenmemesi gerektiği değerlendirilmektedir. İkinci olarak; araştırmada sadece yönetim ve örgüt alanındaki ölçek uyarlama çalışmaları incelendiğinden, bu araştırmanın bulgularının diğer alanlardaki ölçek uyarlama çalışmalarına genellenmesinin araştırmacıları yanlış çıkarımlara götüreceği düşünülmektedir. Buna karş1lık; ölçek uyarlaması ve kültürlerarası karşılaştırma ile ilgili olarak önerilen adımların diğer alanlarda yapılacak olan ölçek uyarlama çalışmalarında da dikkate alınmasının, yapılacak olan çalışmaların geçerlilik ve güvenilirliklerini artıracağ1 değerlendirilmektedir.

Sonuç olarak; yazında ölçek uyarlama sürecine ilişkin temel kabul gören ilke ve adımları takip etmeden, Türkçe'ye uyarlaması yapılan ölçeklerin kullanımı sonucunda elde edilecek bulguların geçerliliği ve güvenilirliği şüphelidir. Bu nedenle; ölçek uyarlama çalışmalarında metodoloji birliğini sağlamak ve hatalı uygulamaları en az düzeye indirgemek amacıyla ölçek uyarlamaya yönelik yazındaki uygulamaların derlenmesi suretiyle araştırmacılar tarafından önerilen temel adımların (bknz. Şekil-2) takip edilmesinin araştırmacılar için faydalı olacağı söylenebilir. 


\section{KAYNAKÇA}

Ægisdóttir, S., Gerstein, L. H. \& Çınarbaş, D. C. (2008). Methodological issues in cross-cultural counseling research equivalence, bias, and translations. The Counseling Psychologist, 36(2), 188-219.

Ægisdóttir, S., Gerstein, L. H. \& Gridley, B. E. (2000). The factorial structure of the expectations about counseling questionnaire-brief form: Some serious questions. Measurement and Evaluation in Counseling and Development, 33(1), 3-20.

American Psychological Association. (2010). Publication manual of the American Psychological Association (6th ed.). Washington, DC: American Psychological Association.

Brislin, R. W. (1970). Back-translation for cross-cultural research. Journal of Cross-Cultural Psychology, 1(3), 185-216.

Brislin, R. W. (1976). Comparative research methodology: Cross-cultural studies. International Journal of Psychology, 11(3), 215-229.

Brislin, R. W. (1986). The wording and translation of research instruments. İçinde W. J. Lonner \& J. W. Berry (Eds.), Field methods in cross-cultural research (ss.137-164). Beverly Hills, CA: Sage.

Brislin, R. W., Lonner, W. J. \& Thorndike, R. M. (1973). Cross-cultural research methods. New York: John Wiley.

Çokluk, Ö., Şekercioğlu, G. \& Büyüköztürk, Ş. (2012). Sosyal bilimler için çok değişkenli istatistik SPSS ve LISREL uygulamaları (2. Baskı). Ankara: Pegem Akademi.

Cronbach, L. J. (1951). Coefficient alpha and the internal structure of tests. Psychometrika, 16(3), 297-334.

Çüm, S. \& Koç, N. (2013). Türkiye'de psikoloji ve eğitim bilimleri dergilerinde yayımlanan ölçek geliştirme ve uyarlama çalışmalarının incelenmesi. Journal of Educational Sciences and Practices, 12(24), 115-135.

Deniz, K. Z. (2007). Psikolojik ölçme aracı uyarlama. Ankara Üniversitesi Eğitim Bilimleri Fakültesi Dergisi, 40(1), 1-16.

DeVellis, R. F. (2003). Scale development: Theory and applications (2nd ed.). CA: Sage.

Ellis, B. B. (1989). Differential item functioning: Implications for test translations. Journal of Applied Psychology, 74(6), 912.

Erdemir, E. (2008). Yönetim ve örgüt araştırmalarında ölçek kullanımı: Yönetim organizasyon kongre bildirileri örneği. İçinde 16. Ulusal Yönetim ve Organizasyon Kongresi bildiriler kitabı (ss.397-403). İstanbul: İstanbul Kültür Üniversitesi Yayınevi.
Field, A. (2009). Discovering statistics using SPSS (3rd ed.). CA: Sage.

Gürbüz, S. (2015). Kuşak farklılıkları: Mit mi, gerçek mi? İş ve Insan Dergisi, 2(1), 39-57.

Gürbüz, S. \& Şahin, F. (2015). Sosyal bilimlerde araştırma yöntemleri (2. Bask1). Ankara: Seçkin Yayıncilik.

Güvendir, M. A. \& Özkan, Y. Ö. (2015). Türkiye'deki eğitim alanında yayımlanan bilimsel dergilerde ölçek geliştirme ve uyarlama konulu makalelerin incelenmesi. Elektronik Sosyal Bilimler Dergisi, 14(52), 23-33.

Hambleton, R. K. (1993). Translating achievement tests for use in cross-national studies. European Journal of Psychological Assessment, 9, 57-68.

Hambleton, R. K. (1996). Guidelines for adapting educational and psychological tests. The Annual Meeting of the National Council on Measurement in Education'da sunulan bildiri (NewYork, NY).

Hambleton, R. K. (2005). Issues, designs and technical guidelines for adapting tests into multiple languages and cultures. İçinde Hambleton, R. K., Merenda, P. F. \& Spielberger, C., D. (Eds.) Adapting educational and psychological tests for cross-cultural assessment. (ss.3-38). NJ: Lawrence Erlbaum Associates.

Hambleton, R. K. \& de Jong, J. H. (2003). Advances in translating and adapting educational and psychological tests. Language Testing, 20(2), 127134.

Hambleton, R. K. \& Patsula, L. (1999). Increasing the validity of adapted tests: Myths to be avoided and guidelines for improving test adaptation practices. Association of Test Publishers, 1(1), 1-13.

Hambleton, R. K. \& Swaminathan, H. (1985). Item response theory: Principles and applications. The Netherlands: Kluwer.

He, J. \& Van de Vijver, F. J. R. (2012). Bias and equivalence in cross-cultural research. Online Readings in Psychology and Culture, 2(2), 8.

Hofstede, G. (1980). Culture's consequences: International differences in work-related values. Beverly Hills, CA: Sage.

House, R., Hanges, P., Javidan, M., Dorfman, P. \& Gupta, V. (2004). Culture, leadership and organizations: The GLOBE study of 62 societies. CA: Sage Publications.

International Test Commission (2005). International guidelines on test adaptation. 3 Ocak 2016, https://www.intestcom.org/files/guideline_test_adapta tion.pdf. 
Jex, S. M. \& Britt, T. W. (2008). Organizational psychology: A scientist-practitioner approach (2nd ed.). New Jersey: John Wiley \& Sons.

Johnson, T. P. (1998). Approaches to equivalence in cross-cultural and cross-national survey research. Zuma Nachrichten Spezial, 3, 1-40.

Mallinckrodt, B. \& Wang, C. C. (2004). Quantitative methods for verifying semantic equivalence of translated research instruments: A Chinese version of the experiences in close relationships scale. Journal of Counseling Psychology,51(3), 368-379.

Miles, M. B. \& Huberman, A. M. (1994). Qualitative data analysis: An expanded sourcebook. CA: Sage.

Özen, Ş. (2000). Türk yönetim/organizasyon yazınında yöntem sorunu: Kongre bildirileri üzerine bir inceleme. DAÜ Turizm Araştırmaları Dergisi, 1(1), 89-118.

Öztürk, N. B., Eroğlu, M. G. \& Kelecioğlu, H. (2015). Eğitim Alanında Yapılan Ölçek Uyarlama Makalelerinin İncelenmesi. Eğitim ve Bilim, 40(178), 123-137.

Sargut, S. (2010). Kültürlerarası farklılaşma ve yönetim. (3. Baskı). Ankara: İmge Kitabevi.

Schuman, H. (1966). The random probe: a technique for evaluating the validity of closed questions. American Sociological Review, 31(2), 218-222.

Tavşancıl, E. \& Aslan, A. E. (2001). İçerik analizi ve uygulama örnekleri. İstanbul: Epsilon Yayınları.

Triandis, H. C. (1995). Individualism and collectivism. Boulder, CO: Westview Press.

Triandis, H. C. (2000). Dialectics between cultural and cross-cultural psychology. Asian Journal of Social Psychology, 3(3), 185-195.

United Nations (2015). 2015 Human development report. 19 Kasim 2015, http://hdr.undp.org/sites/default/files/2015_human_de velopment_report_1.pdf.

Van de Vijver, F. J. R. (1998). Towards a theory of bias and equivalence. Zuma Nachrichten Spezial, 3, 41-65.

Van de Vijver, F. J. R. (2001). The evolution of crosscultural research methods. İçinde D. Matsumoto (Ed.), Handbook of culture and psychology (ss.7797). New York: Oxford University Press.

Van de Vijver, F. J. R. \& Hambleton, R. K. (1996). Translating tests. European Psychologist, 1(2), 89-99.

Van de Vijver, F. J. R. \& Leung, K. (1997a). Methods and data analysis for cross-cultural research. Thousand Oaks, CA: Sage.
Van de Vijver, F. J. R. \& Leung, K. (1997b). Methods and data analysis of comparative research. İçinde Berry, J., W., Poortinga, Y.,H. \& Pandey, J. (Eds.), Handbook of cross-cultural psychology, (2. Bask1, Cilt1, ss.257-300). Boston: Allyn\&Bacon.

Van de Vijver, F. J. R. \& Poortinga, Y. H. (1997). Towards an integrated analysis of bias in crosscultural assessment. European Journal of Psychological Assessment,13(1), 29-37.

Van de Vijver, F. J. R. \& Tanzer, N. K. (2004). Bias and equivalence in cross-cultural assessment: An overview. Revue Européenne de Psychologie Appliquée / European Review of Applied Psychology, 54(2), 119-135.

Werner, O. \& Campbell, D. T. (1970). Translating, working through interpreters, and the problem of decentering. İçinde R. Naroll \& R. Hohen (Eds.), A handbook of methods in cultural anthropology (s.398420). New York: American Museum of Natural History.

Zumbo, B. D. (2003). Does item-level DIF manifest itself in scale-level analyses? Implications for translating language tests. Language Testing, 20(2), 136-147. 